UNIVERSIDADE DE SÃO PAULO

FACULDADE DE FILOSOFIA, CIÊNCIAS E LETRAS DE RIBEIRÃO PRETO PROGRAMA DE PÓS-GRADUAÇÃO EM BIOLOGIA COMPARADA

Ecosystem functioning of canopy and turf-forming algae: potential supply of invertebrate prey to pelagic consumers

Funcionamento ecossistêmico de dosséis e tapetes de macroalgas: potencial suprimento de presas para consumidores pelágicos

Carla Kühl de Figueiredo

Dissertação apresentada à Faculdade de Filosofia, Ciências e Letras de Ribeirão Preto da Universidade de São Paulo, como parte das exigências para obtenção do título de Mestre em Ciências, obtido no Programa de PósGraduação em Biologia Comparada

Ribeirão Preto - SP 
UNIVERSIDADE DE SÃO PAULO

FACULDADE DE FILOSOFIA, CIÊNCIAS E LETRAS DE RIBEIRÃO PRETO

PROGRAMA DE PÓS-GRADUAÇÃO EM BIOLOGIA COMPARADA

Ecosystem functioning of canopy and turf-forming algae: potential supply of invertebrate prey to pelagic consumers

Funcionamento ecossistêmico de dosséis e tapetes de macroalgas: potencial suprimento de presas para consumidores pelágicos

Carla Kühl de Figueiredo

Dissertação apresentada à Faculdade de Filosofia, Ciências e Letras de Ribeirão Preto da Universidade de São Paulo, como parte das exigências para obtenção do título de Mestre em Ciências, obtido no Programa de PósGraduação em Biologia Comparada.

Orientador: Prof. Dr. Augusto Alberto Valero Flores.

Versão corrigida contendo as alterações solicitadas pela comissão julgadora em 19 de fevereiro de 2020. A versão original encontrase em acervo reservado na Biblioteca da FFCLRP/USP e na Biblioteca Digital de Teses e Dissertações da USP (BDTD).

Ribeirão Preto - SP 
Autorizo a reprodução e divulgação total ou parcial deste trabalho, por qualquer meio convencional ou eletrônico, para fins de estudo e pesquisa, desde que citada a fonte

Figueiredo, Carla Kühl

"Funcionamento ecossistêmico de dosséis e tapetes de macroalgas: potencial suprimento de presas para consumidores pelágicos"

$56 \mathrm{p}$

Dissertação apresentada à Faculdade de Filosofia, Ciências e Letras de Ribeirão Preto da Universidade de São Paulo como parte das exigências para obtenção do título de mestre em Ciências. Área: Biologia Comparada.

Orientador: Prof. Dr. Augusto Alberto Valero Flores

1. engenharia de ecossitemas 2 . mudança de fase 3 . competição 4 . sucessão ecológica 5. peixe de recife 
Dedico esta dissertação aos meus pais Helena e Ronaldo, por todo amor e apoio 


\section{Agradecimentos}

Ao meu orientador Augusto Alberto Valero Flores pela confiança, receptividade quando pedi sua orientação, pela ajuda sempre que precisei, pelas saídas de campo, por corrigir meus erros, estar sempre disponível quando precisei, pelos finais de semana de muito trabalho, e principalmente por me proporcionar um grande crescimento.

O presente trabalho foi realizado com apoio da Coordenação de Aperfeiçoamento de Pessoal de Nível Superior - Brasil (CAPES) - Código de Financiamento 001.

À Fundação de Amparo à Pesquisa do Estado de São Paulo (FAPESP) pelo apoio financeiro concedido para o projeto FAPESP (2018/11044-2).

À Faculdade de Filosofia, Ciências e Letras e ao Programa de pós em Biologia Comparada por me receber como mestranda, pelo suporte durante meu mestrado e à Vera Cássia Cicilin pela ajuda administrativa e burocrática a distância.

Ao Centro de Biologia Marinha da Universidade de São Paulo (CEBIMar/USP) pelo espaço e infraestrutura concedida para a realização deste projeto.

Membros da banca de qualificação, professores Tomás e Flávio e pós-doc Lorian pelas muitas contribuições, questionamentos e ajuda na continuidade do meu projeto.

Ao Rafael Campos Duarte (Mogli) pela ajuda e ideias durante meu mestrado.

Às cebimarianas, mulheres maravilhosas da ciência! Carla, Aline, Camila Obata, Stella, Karine, Cláudia, Juliana, Laiza, Isa, Camila Barreto, Déia, Lígia, Quel, Kátia, Bruna, Leilaine e Ariely, pelo dia-a-dia, pelas risadas, incentivo, correções, ajuda e principalmente por toda a a inspiração e força que cada uma representa na ciência.

Em especial às 'Guquetes', companheiras de laboratório, Carla, Ju, Déia e Camila B. pelo ambiente de ajuda, por sempre apoiarem uma a outra e pelos conselhos na área.

Aos técnicos do Cebimar, Zé, Edu e Alex pelo suporte. Em especial ao Zé pela ajuda em todas as coletas, por estar disposto e me ajudar sempre que precisei, pelo bom humor de sempre, incontáveis cafézinhos da tarde, conversas animadas e pelas caronas musicais.

Ao Jerônimo pela ideia criativa, construção e manejo da bomba de sucção que foi essencial para as coletas desse projeto.

À equipe de coleta Augusto, Zé e Jerônimo que foram de extrema importância sem os quais este projeto não seria concretizado, pelas saídas divertidas com chuva, sol, ótima e péssima visibilidades. 
Aos professores e pós doutores do CEBIMAR/USP Áurea, Álvaro, Marcelo, Claúdio e Juan pelo convívio e por cada contribuição ao longo desses dois anos e meio de Cebimar.

Todos funcionários do CEBIMAR/USP que estiveram presentes em cada dia desse mestrado. Às meninas da limpeza, Wanderleia e Silvia por manter sempre a sala de estudos, laboratórios e dependências do Cebimar nas melhores condições. Ao seu Zé pela comida saborosa e pelo sorriso de todo dia. À Acadêmica pelo apoio logístico em especial à Simone pelas conversas depois do almoço e por sempre estar disposta a ajudar. À administração que auxiliou nas compras de material e no financeiro do projeto FAPESP.

Meninas do meu antigo apartamento de Ribeirão Preto que me abrigaram sempre que precisei retornar para disciplinas e congressos.

Meu muito obrigado às minhas amigas queridas, Amanda, Larissa, Rafaela e Olívia pelo suporte, incentivo e conforto mesmo de longe por mensagens, pelas conversas engraçadas ou sérias quando necessário, e pelo melhor gosto musical que nos mantém unidas e proporciona os nossos digníssimos encontros. Especialmente à minha amiga Olívia, roommate que sempre me ouve, aconselha e suporta mesmo não morando mais juntas.

Minha amiga Thamires, pelos muitos anos de amizade, por sempre lembrar de mim e torcer pela minha carreira.

Aos meus familiares que torceram por mim e me dão apoio sempre que podem.

E por fim um agradecimento muito especial aos meus pais Helena e Ronaldo, por todo o carinho, pelo auxílio financeiro quando precisei, por me confortar, por estar ao meu lado sempre, por torcer por mim em cada vitória, pelas orações e por me apoiar em todas as decisões, obrigada por tudo! 
"Mas o amanhecer virá, mesmo que a noite seja dolorosa Vamos superar isso, até que o futuro venha Não vamos mais parar Decida para si mesmo o que significa ser feliz” 


\section{Index}

Resumo.

Abstract.......................................................................... 11

General Introduction............................................................... 12

The importance of canopy-forming macroalgae ............................................. 12

Phase-shifts and the replacement of algal canopies by alternative habitats of lower complexity

Sargassum beds in the SW Atlantic

Environmental management and conservation

References.

Main Objectives

Chapter 1. Ecosystem function of canopy and turf-forming algae: potential supply of invertebrate prey to pelagic consumers....................................... 23

Abstract............................................................................ 23

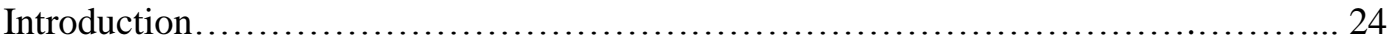

Material and Methods.................................................................... 26

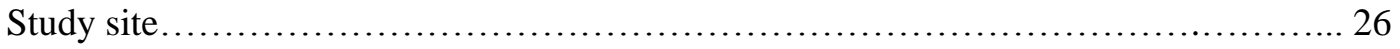

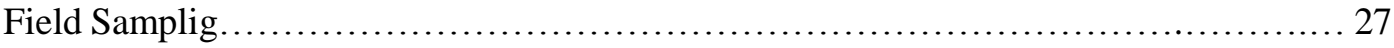

Canopy $v$ s turf comparisons...................................................... 27

Temporal assembly of invertebrates associated to canopy-forming algae .................... 27

Laboratory procedures......................................................... 28

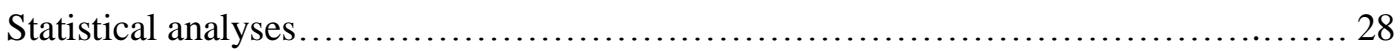

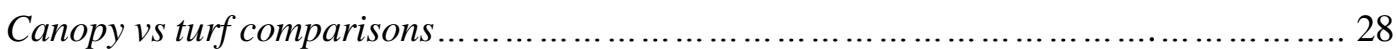




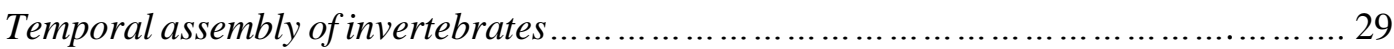

Results................................................................. 30

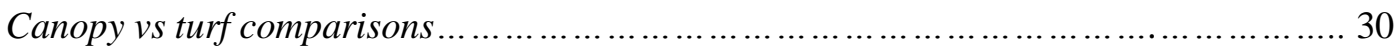

Seasonal cover of canopy-forming algae and the assembly of invertebrates...................34

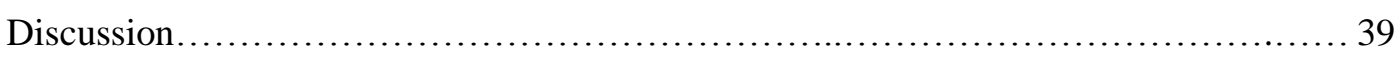

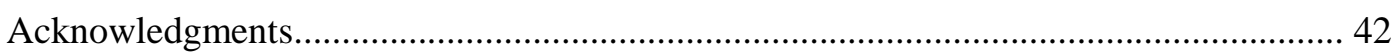

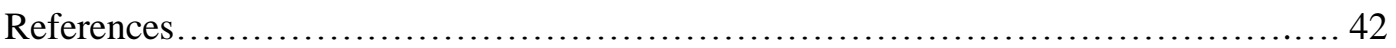

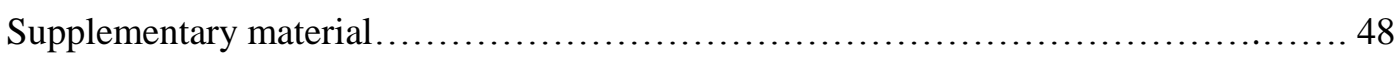

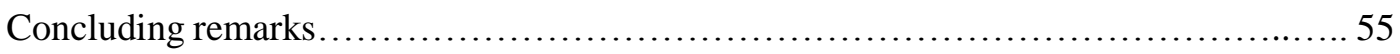




\section{Resumo}

As algas formadoras de dossel podem fornecer recursos tróficos e complexidade estrutural para uma ampla gama de invertebrados móveis, que por sua vez podem sustentar consumidores pelágicos de níveis tróficos mais altos. No entanto, os dosséis de algas estão declinando em todo o mundo e substituídos por tapetes de macroalgas menos complexos, que podem dominar as paisagens dos recifes. Aqui, comparamos primeiro associações de invertebrados móveis associadas às principais algas formadoras de dossel (Sargassum spp. e Galaxaura marginata) e algas formadoras de tapetes (filamentoso e calcário articulado) e depois avaliamos se, e como, as associações de invertebrados que habitam o dossel flutuam afastando da linha de base dos tapetes durante a estação de floração do principal habitat de dossel (Sargassum). Abundância, biomassa e diversidade quase sempre diferiram entre dosséis e tapetes nos locais de amostragem, enquanto as diferenças nos principais tipos de algas funcionais estavam quase ausentes. Surpreendentemente, porém, nenhuma dessas métricas gerais variou de maneira consistente nos locais de amostragem. Diferentemente, a estrutura da associação diferia consistentemente entre dosséis e tapetes, com invertebrados de exoesqueleto rígido (como gastrópodes e caranguejos braquiúros) e de corpo mole (principalmente poliquetas e platelmintos) caracterizando associações de dossel e tapete, respectivamente. A divergência entre associações de invertebrados em dosséis e tapetes aumentou à medida que a estação de floração do dossel avançava. Notavelmente, enquanto a estrutura da associação de invertebrados permaneceu inalterada nos tapetes, a sucessão rápida de ofiuróides e anfípodes foram seguidos por gastrópodes, bivalves e ostracodas de concha rígida em Sargassum, onde se tornaram dominantes e diminuíram a diversidade mais tarde na temporada. Como presas de exoesqueleto rígido são itens preferenciais para as principais espécies de peixes invertívoros da região, os resultados indicam que os dosséis desempenham um papel particularmente importante no fornecimento de recursos tróficos aos consumidores pelágicos.

Palavras-chave: engenharia de ecossistema, mudanças de fase, competição, sucessão ecológica, peixe de recife 


\begin{abstract}
Canopy-forming algae may provide trophic resources and structural complexity for a wide array of mobile invertebrates, which in turn may sustain pelagic consumers of higher trophic levels. However, algal canopies are declining worldwide and replaced by less-complex macroalgal turfs which may dominate reefscapes. Here, we first compare the assemblages of mobile invertebrates associated to main canopy-forming (Sargassum spp. and Galaxaura marginata) and turf-forming algae (filamentous and articulated coralline turf), and then assess if, and how, canopy-dwelling invertebrate assemblages drift away from the turf baseline during the blooming season of the main canopy habitat (Sargassum). Abundance, biomass and diversity almost always differed between canopies and turfs at sampling sites, while differences within main functional algal types were nearly absent. But, surprisingly, none of those overall metrics varied in any consistent way across sampling sites. Differently, the assemblage structure consistently differed between canopies and turfs, with hardbodied (as gastropods and brachyuran crabs), and soft-bodied (mainly polychaetes and flatworms) invertebrates characterizing canopy and turf assemblages, respectively. The divergence between invertebrate assemblages at canopies and turfs increased as the canopy-blooming season advanced. Notably, while the invertebrate assemblage structure remained unaltered at turfs, early-successional brittle stars and amphipods were followed by hard-shelled gastropods, bivalves and ostracods in Sargassum, where they become dominant and decreased diversity later on within the season. As hardshelled prey are preferred items for the main invertivore fish species in the area, results indicate that canopies play a particularly important role in the provisioning of trophic resources to pelagic consumers.
\end{abstract}

Keywords: ecosystem engineering, phase-shifts, competition, ecological succession, reef fish 


\section{General Introduction}

The importance of canopy-forming macroalgae

Marine coastal environments host rich, diverse and productive biological communities, providing food, shelter, and protection for many organisms, and having been widely exploited by humans in many different ways (Lilley \& Schiel 2006, Matias et al. 2015, Martins et al. 2016, Piazzi et al. 2018). Still, seascapes are highly heterogeneous and most biological diversity and productivity is concentrated at discrete hotspots, where limiting resources elsewhere can be plentiful. In rocky reef systems, several types of algae can build-up densely vegetated areas amidst rather simplified habitats, such as barren grounds or algal turf beds, being considered 'ecosystem engineers', sustaining important ecosystem services such as the supply of food and shelter for many other species (Schmidt \& Scheibling 2007, Orlando-Bonaca \& Rotter 2018).

Benthic macroalgal beds are considered very productive systems (Tait \& Schiel 2011, Miller et al. 2009a), growing to canopy height, and altering the physical structure of reef shorelines, mostly from the low intertidal zone to shallow depths of marine ecosystems (Rindi et al. 2017). In warmtemperate and tropical coastal habitats worldwide, macroalgal beds are often dominant components of the benthos (Schmidt \& Scheibling 2007, Strain et al. 2014), forming a three-dimensional canopy structure that affect important physical variables such as light penetration in the water column (Airoldi et al. 1995, Lilley \& Schiel 2006, Martins et al. 2016), water flow (Schmidt \& Scheibling 2007, O'Brien \& Scheibling 2018), sediment transport and deposition (Airoldi 2003, Connel 2005) and pH (Hernández et al. 2018, Layton et al. 2019). Also, large canopy-forming algae contribute to the development of urbanized coasts providing cleaner water through the filtration of nutrients and protecting shorelines from erosion by attenuating and dissipating wave energy (Strain et al. 2014, Martins et al. 2016, Filbee-Dexter \& Wernberg 2018).

Canopy-forming macroalgae are also colonized by a diverse and abundant fauna of mobile benthic invertebrates (Wikstrom \& Kautsky 2007, Filbee-Dexter et al. 2016, Lutz et al. 2019), normally dominated by amphipods, isopods, gastropods and polychaetes (Tano et al. 2016), and constitute both reproduction sites and nursery habitats for many other larger species (Hinz et al. 2019), where juveniles find effective shelter from predators and adequate foraging grounds (Edgar et al. 2004, Filbee-Dexter et al. 2016). As such, canopy-forming algae constitute a semi-closed biodiversity loop, containing a self-sustained food-web, which include the main algal host and their epiphytic algal assemblages as a basal trophic level, direct mesoherbivore grazers and detritivores as intermediate levels and small fish and invertebrate predators as high within-canopy trophic levels. Different components of this so-called associated fauna assemblage may be used by an array of more or less specialized water column predators (mostly fish, but eventually swimming and crawling large 
consumers, such as crabs), including commercially exploited species (Vásquez et al. 2014, Bennet et al. 2016, Filbee-Dexter \& Wernberg 2018).

\section{Phase-shifts and the replacement of algal canopies by alternative habitats of lower complexity}

There is an increasing concern of the significant loss of complex habitats in both temperate and tropical coastal marine ecosystems. The decline of foundation species, namely reef-building corals, seagrass meadows and canopy-forming macroalgae, with the uprise of more opportunistic species such as mussels and turf-forming algae, preempting the newly available space, has been repeatedly reported for many different coastal areas worldwide (Benedetti-Cecchi et al. 2001, Airoldi et al. 2008, Gorman et al. 2009, Perkol-Finkel \& Airoldi 2010, Piazzi \& Ceccherelli 2019, Gorman et al. in press). Turfs, in particular, are highly tolerant to different sources of environmental stress and disturbance (Perkol-Finkel \& Airoldi 2010, Schiel \& Lilley 2011, Connel et al. 2014), forming a dense matrix of low-lying mat (from $\mathrm{mm}$ to a few $\mathrm{cm}$ height), composed by single or multi-species assemblages, mostly thinly filamentous, or other small species with more rigid branches (i.e. articulated coralline algae).

So far, interactions between canopy-forming and turf-forming algae were mostly examined in temperate coastal areas, and mainly addressing the loss of kelp forests. The evidence available indicates that competition between these two algal functional types works in the two directions. Large macroalgae, such as Cystoseira and different kelp species, may inhibit the development of turfs mostly through shading (Filbee-Dexter et al. 2016) and abrasion (whiplash; O’Brien \& Scheibling 2018). Otherwise, turfs can inhibit canopy regeneration by negatively affecting early benthic stages of canopy-forming algae (Gorman \& Connell 2009, Perkol-Finkel \& Airoldi 2010), through negative allelopathy, sediment retention (a positive feedback mechanism; Connel et al. 2014), or even shading of propagules (Eriksson et al. 2006, Wernberg \& Connel 2008). Less common, turfs can still displace large algal fronds, otherwise grown to a superior-competitor size, when their capacity to retain sediments is unusually high (O'Brien \& Scheibling 2018). Much probably, however, the canopy-toturf shift is not an outcome of the isolated effects of competition, but mostly the modulation of those biological interactions by several different anthropogenic stressors, such as heavy metal pollution, increased sediment loads, nutrient enrichment, and global climate change, including ocean warming and acidification, as well as the increased frequency and strength of storms causing large-scale detachment of canopies (Schiel \& Lilley 2011, Strain et al. 2014, Filbee-Dexter \& Wernberg 2018, O'Brien \& Scheibling 2018). Contrary to late-successional canopies, more opportunistic algal functional types, such as turfs, actually take advantage of surplus nutrients to more rapidly colonize reef space, and are more resistant to the decay of water quality (Littler \& Littler 2013, Bulleri et al. 2018, Provost et al. 2017). As such, algal turfs tend to become more dominant as environmental 
stressors build up, up to a point that recovery of macroalgal canopies, including whole kelp forests, becomes unlikely. Phase-shifts to impoverished states constitute a major threat to marine diversity, directly affecting a number of important ecosystem functions (Airoldi et al. 2008). Major drivers of community dynamics, including recruitment, competition and predation (Milazzo et al. 2004), become fundamentally altered (Tait \& Schiel 2011, Connel et al. 2014) paving the grounds for cascading effects leading to overall biodiversity loss (Wikstrom \& Kautsky 2007, Piazzi et al. 2018) and the collapse of ecosystem services (Martins et al. 2016, Rindi et al. 2017) that had historically benefitted human settlements.

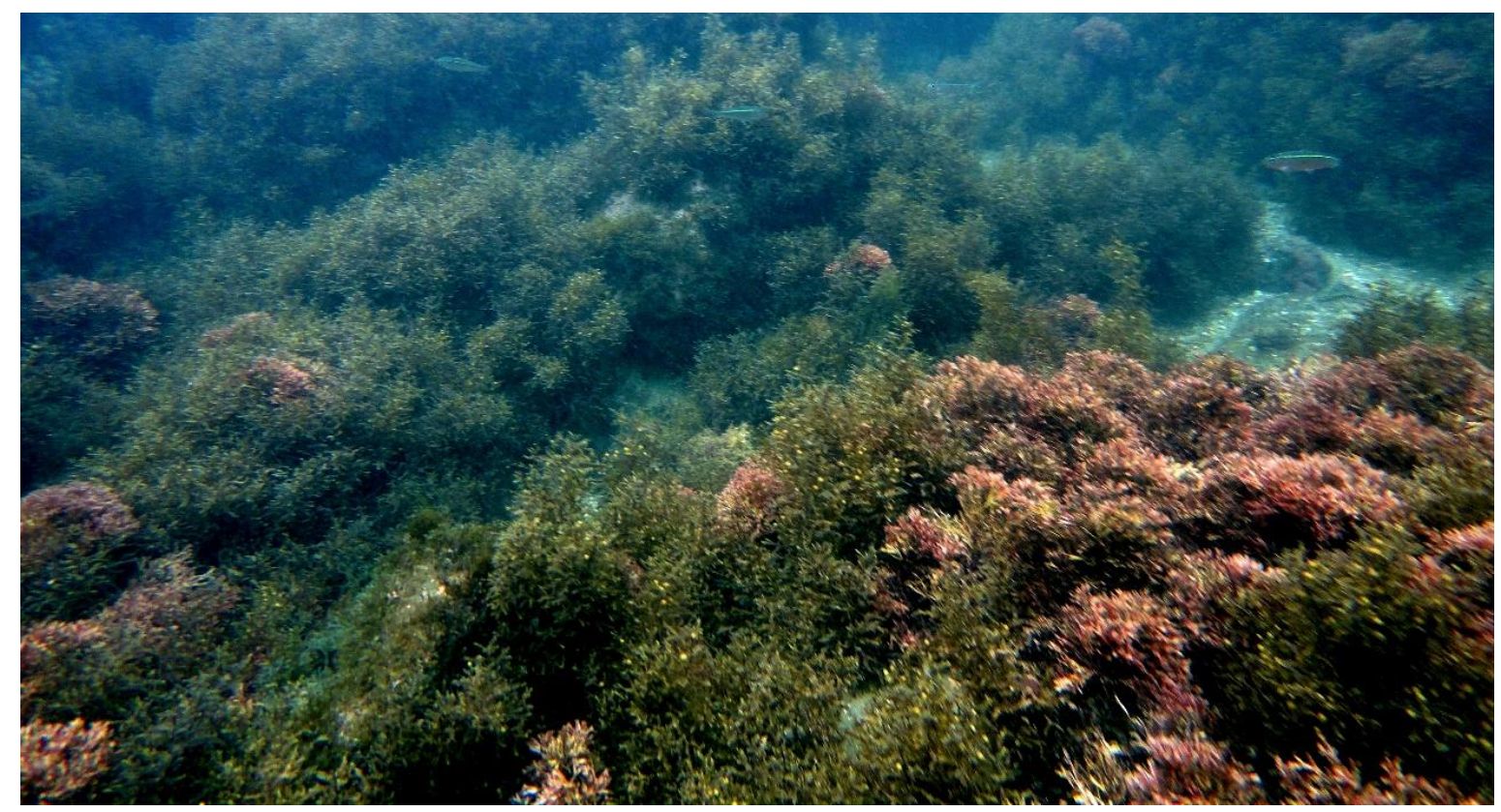

Fig. 1. Canopy- forming macroalgae in the São Sebastião Channel dominated by Sargassum spp. and, to a lesser extent the reddish canopy of Galaxaura marginata. Photo: Rafael Campos Duarte.

\section{Sargassum beds in the SW Atlantic}

In warm tropical waters, macroalgal canopies tend to be smaller (although large kelp forests do develop at depth, including in the subtropical SW Atlantic, (Joly \& Oliveira Filho 1967, Marins et al. 2014), but highly speciose, potentially providing high functional redundancy from the lower intertidal to shallow waters up to $10 \mathrm{~m}$. Even so, two seaweeds disproportionately provide canopy habitat in the northern coast of São Paulo State; Dichotomaria (= Galaxaura) marginata (Ellis \& Solander) and species of the genus Sargassum C.Agardh (Fig. 1). During summertime, the canopy of these two groups may cover more than $70 \%$ of the available reef space in the São Sebastião Channel (see 'Results'). Although more seasonal, the brown algae Sargassum spp. may be regarded as the principal canopy component of local reefs because they are more abundant during most of the 
year and their thallii grow much higher (as in Fig. 2). These macroalgae are very important and, as well as canopy-forming macroalgae from temperate reefs, play an important role in the reef ecosystem. In southeast Brazil, the main blooming season takes place during spring and summer (Godoy \& Coutinho 2002, Reis et al. 2003, Széchy et al. 2006), when they harbor a well-described and rich invertebrate fauna (e.g. Jacobucci \& Leite 2006, Mafra \& Cunha 2006, Marinho-Soriano et al. 2006, Bertagnolli et al. 2014, Jacobucci et al. 2019). During most of this season, several different species compose the majorly Sargassum bed as epiphytic plants (especially algae of the genera Hypnea J.V.Lamouroux and Canistrocarpus de Paula \& De Clerck; Fig. 2), which increase the diversity and abundance of the overall associated fauna (Leite \& Turra 2003). However, to the best of our knowledge, no studies so far had compared, in a systematic way, the assemblages of mobile invertebrates associated to Sargassum to those living in other canopy-forming algae, or even to other important macroalgae, notably algal turfs. Such comparisons would however be very important to assess the relative role of Sargassum to the overall diversity of reef systems, and their relevance to the supply of invertebrate prey to water column consumers.

Differently from different warm-temperate regions, where Sargassum is invasive (Stæhr et al. 2000, Strong et al. 2006, Salvaterra et al. 2013) and detached floating fronds, in addition to fully pelagic strains, can jeopardize environmental health ('golden tides', Milledge \& Harvey 2016, van Tussenbroek et al. 2017, Rodríguez-Martínez et al. 2019), all the 13 infrageneric Sargassum taxa found in São Paulo State are native (de Paula 1988). However, a recent study has showed that Sargassum species, overall, have been steadily declining from the 1980's to present days along the states of Santa Catarina, São Paulo and Rio de Janeiro in Brazil (Gorman et al. in press). The same trend has been observed in this same study for Dichotomaria / Galaxaura. A better understanding of the ecological function of canopy-forming species in the SW Atlantic, particularly in the SW coast of Brazil, is therefore urgently needed. 


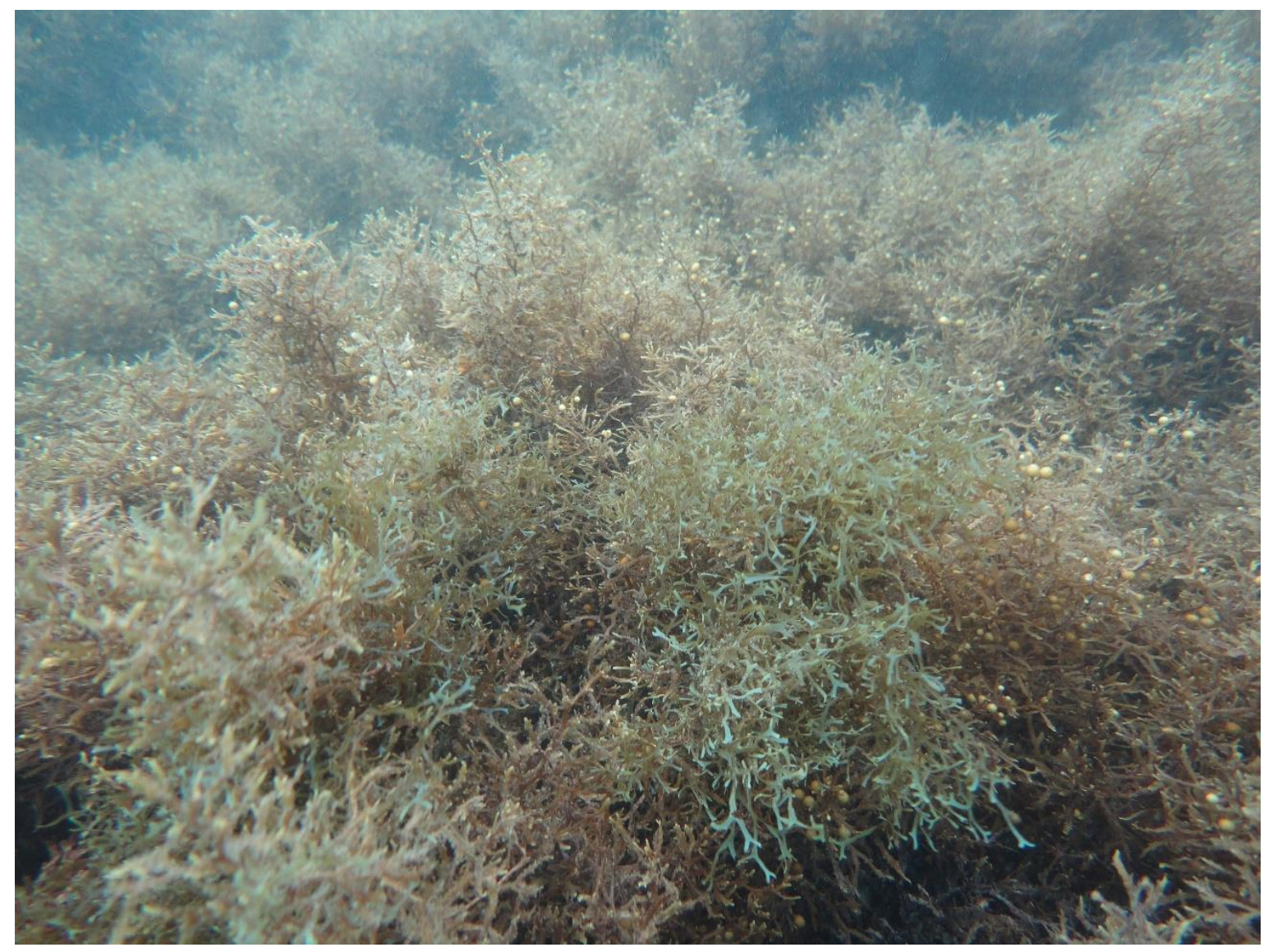

Fig. 2. Close view of a seaweed canopy dominated by Sargassum spp. (possibly S. furcatum) from the São Sebastião Channel. Note the abundance of associated epiphytic species, such as Canistrocarpus cervicornis (Kützing). Photo: Rafael Campos Duarte.

\section{Environmental management and conservation}

As declining worldwide and raising serious concerns, macroalgal canopies are presently under protection in many coastal regions and also broadly considered in management plans of many others (Airoldi et al. 2008). Undertaking such conservation policies has been driven by the now consensual view that canopy loss ultimately drives the whole ecosystem to an impoverished state, with lower physical complexity and more restricted ecosystem functioning, ultimately leading to losses of important services to humans (Strain et al. 2014, Tano et al. 2016).

Without intervention, impoverished reef-habitats may remain unaltered over decades (Strain et al. 2014). Orlando-Bonaca \& Rotter (2018) advocate that any efforts to solve the problem should first consider the amelioration of environmental conditions, especially the reduction of nutrient concentrations at enclosed bays estuaries. Others, however, have successfully attempted state reversals through restoration, including the translocation of recruits and the removal of large turf areas (Connel et al. 2008, Gorman \& Connel 2009, Perkol-Finkel \& Airoldi 2010). In some cases, 
however, reversals form turf to canopy dominated states may take enduring work over several generations of canopy-forming algae (Benedetti-Cecchi et al. 2001).

\section{References}

Airoldi L (2003) The effecys of sedimentation on rocky costal assemblages. Oceanography and Marine Biology Annual Review 41:161-236

Airoldi L, Balata D, Beck MW (2008) The Gray Zone: Relationships between habitat loss and marine diversity and their applications in conservation. Journal of Experimental Marine Biology and Ecology 366:8-15

Airoldi L, Rindi F, Cinelli F (1995) Structure, Seasonal Dynamics and Reproductive Phenology of a Filamentous Turf Assemblage on a Sediment Influenced, Rocky Subtidal Shore. Botanica Marina 38:227238

Benedetti-Cecchi L, Pannacciulli F, Bulleri F, Moschella PS, Airoldi L, Relini G, Cinelli F (2001) Predicting the consequences of anthropogenic disturbance: Large-scale effects of loss of canopy algae on rocky shores. Marine Ecology Progress Series 214:137-150

Bennett S, Wernberg T, Connell SD, Hobday AJ, Johnson CR, Poloczanska ES (2016) The 'Great Southern Reef': Social, ecological and economic value of Australia's neglected kelp forests. Marine and Freshwater Research 67:47-56

Bertagnolli C, Espindola APD, Kleinübing SJ, Tasic L, da Silva MGC (2014) Sargassum filipendula alginate from Brazil: Seasonal influence and characteristics. Carbohydrate polymers 111: 619-623

Bulleri F, Cucco A, Dal Bello M, Maggi E, Ravaglioli C, Benedetti-Cecchi L (2018) The role of wave-exposure and human impacts in regulating the distribution of alternative habitats on NW Mediterranean rocky reefs. Estuarine, Coastal and Shelf Science 201:114-122

Connell SD (2005) Assembly and maintenance of subtidal habitat heterogeneity: Synergistic effects of light penetration and sedimentation. Marine Ecology Progress Series 289:53-61

Connell SD, Russell BD, Turner DJ, Shepherd SA, Kildea T, Miller D, Airoldi L, Cheshire A (2008) Recovering a lost baseline: Missing kelp forests from a metropolitan coast. Marine Ecology Progress Series 360:63-72

Connell SD, Foster MS, Airoldi L (2014) What are algal turfs? Towards a better description of turfs. Marine Ecology Progress Series 495:299-307

de Paula EJ (1988) O Gênero Sargassum C. Ag. (Phaeophyta - Fucales) no Litoral do Estado de São Paulo, Brasil. Boletim de Botânica 10:65

Edgar GJ, Barrett NS, Morton AJ, Samson CR (2004) Effects of algal canopy clearance on plant, fish and macroinvertebrate communities on eastern Tasmanian reefs. Journal of Experimental Marine Biology and Ecology 312:67-87 
Eriksson BK, Rubach A, Hillebrand H (2006) Biotic habitat complexity controls species diversity and nutrient effects on net biomass production. Ecology 87:246-254

Filbee-Dexter K, Feehan CJ, Scheibling RE (2016) Large-scale degradation of a kelp ecosystem in an ocean warming hotspot. Marine Ecology Progress Series 543:141-152

Filbee-Dexter K,Wernberg T (2018) Rise of Turfs: A New Battlefront for Globally Declining Kelp Forests. BioScience 68:64-76

Godoy EA, Coutinho R (2002) Can artificial beds of plastic mimics compensate for seasonal absence of natural beds of Sargassum furcatum? ICES Journal of Marine Science 59: S111-S115

Gorman D, Connell SD (2009) Recovering subtidal forests in human-dominated landscapes. Journal of Applied Ecology 46:1258-1265

Gorman D, Russell BD, Connell SD (2009) Land-to-sea connectivity: Linking human-derived terrestrial subsidies to subtidal habitat change on open rocky coasts. Ecological Applications 19:1114-1126

Gorman D, Horta P, Flores AAV, Turra A, Berchez FAS, Batista MB, Lopes Filho ES, Melo MS, Ignacio BL, Carneiro IM, Széchy MTM (in press) Decadal losses of canopy-forming algae along the warm temperate. Global Change Biology

Hernández CA, Sangil C, Fanai A, Hernández JC (2018) Macroalgal response to a warmer ocean with higher $\mathrm{CO}_{2}$ concentration. Marine Environmental Research 136:99-105

Hinz H, Reñones O, Gouraguine A, Johnson AF, Moranta J (2019) Fish nursery value of algae habitats in temperate coastal reefs. PeerJ 2019:1-27

Jacobucci GB, Leite FP (2006) Biologia populacional das espécies de Ampithoidae (Crustacea, Amphipoda) associadas a Sargassum filipendula (Phaeophyta, Fucales) na Praia da Fortaleza, Ubatuba, São Paulo, Brasil. Revista Brasileira de Zoologia 23: 1207-1216

Jacobucci GB, Vieira EA, Leite FPP (2019) Influence of a narrow depth gradient on the spatial structure of Sargassum peracarid assemblages in Southeastern Brazil. Marine Biodiversity 49:1001-1011

Joly AB, Oliveira Filho EC (1967) Two Brazilian laminarians. Publicações do Instituto de Pesquisas da Marinha 4:1-13

Layton C, Cameron MJ, Shelamoff V, Fernández PA, Britton D, Hurd CL, Wright JT, Johnson CR (2019) Chemical microenvironments within macroalgal assemblages: Implications for the inhibition of kelp recruitment by turf algae. Limnology and Oceanography 64:1600-1613

Leite FPP, Turra A (2003) Temporal variation in Sargassum biomass, Hypnea epiphytism and associated fauna. Brazilian Archives of Biology and Technology 46:665-671

Lilley SA, Schiel DR (2006) Community effects following the deletion of a habitat-forming alga from rocky marine shores. Oecologia 148:672-681 
Littler MM, Littler DS (2013) The nature of turf and boring algae and their interactions on reefs. In: Lang MA, Marinelli RL, Roberts SJ, Taylor PR (eds) Research and discoveries: the revolution of science through scuba. Smithsonian Institution Scholarly Press Washington D.C. 213-217

Lutz ML, Minchinton TE, Davis AR (2019) Differences in architecture between native and non-indigenous macroalgae influence associations with epifauna. Journal of Experimental Marine Biology and Ecology 514-515:76-86

Mafra Jr LL, Cunha SR (2006) Sargassum cymosum (Phaeophyceae) in southern Brazil: Seasonality of biomass, recovery after harvest and alginate yield. Journal of Coastal

Marinho-Soriano E, Fonseca PC, Carneiro MAA, Moreira WSC (2006) Seasonal variation in the chemical composition of two tropical seaweeds. Bioresource Technology 97(18): 2402-2406

Marins BV, Amado-Filho GM, Barbarino E, Pereira-Filho GH, Longo LL (2014) Seasonal changes in population structure of the tropical deep-water kelp Laminaria abyssalis. Phycological Research 62:5562

Martins GM, Hipólito C, Parreira F, Prestes AC, Dionísio MA, Azevedo JM, Neto AI (2016) Differences in the structure and functioning of two communities: Frondose and turf-forming macroalgal dominated habitats. Marine environmental research 116:71-77

Matias MG, Arenas F, Rubal M, Pinto IS (2015) Macroalgal composition determines the structure of benthic assemblages colonizing fragmented habitats. PloS one 10(11): e0142289

Milazzo M, Badalamenti F, Riggio S, Chemello R (2004) Patterns of algal recovery and small-scale effects of canopy removal as a result of human trampling on a Mediterranean rocky shallow community. Biological Conservation 117:191-202

Milledge JJ, Harvey PJ (2016) Golden Tides: Problem or golden opportunity? The valorisation of Sargassum from beach inundations. Journal of Marine Science and Engineering 2016, 4.3: 60

Miller RJ, Reed DC, Brzezinski MA (2009) Community structure and productivity of subtidal turf and foliose algal assemblages. Marine Ecology Progress Series 388:1-11

O’Brien JM, Scheibling RE (2018) Turf wars: Competition between foundation and turf-forming species on temperate and tropical reefs and its role in regime shifts. Marine Ecology Progress Series 590:1-17

Orlando-Bonaca M, Rotter A (2018) Any signs of replacement of canopy-forming algae by turf-forming algae in the northern Adriatic Sea? Ecological Indicators 87:272-284

Perkol-Finkel S, Airoldi L (2010) Loss and recovery potential of marine habitats: An experimental study of factors maintaining resilience in subtidal algal forests at the Adriatic Sea. PLoS one 2010 (5)5 e10791

Piazzi L, Bonaviri C, Castelli A, Ceccherelli G, Costa G, Curini-Galletti M, Langeneck J, Manconi R, Montefalcone M, Pipitone C, Rosso A, Pinna S (2018) Biodiversity in canopy-forming algae: Structure and spatial variability of the Mediterranean Cystoseira assemblages. Estuarine, Coastal and Shelf Science 207:132-141 
Piazzi L, Ceccherelli G (2019) Effect of sea urchin human harvest in promoting canopy forming algae restoration. Estuarine, Coastal and Shelf Science 219:273-277

Provost EJ, Kelaher BP, Dworjanyn SA, Russell BD, Connell SD, Ghedini G, Gillanders BM, Figueira WI, Coleman MA (2017) Climate-driven disparities among ecological interactions threaten kelp forest persistence. Global Change Biology 23:353-361

Reis RP, Leal MCR, Yoneshigue-Valentin Y, Belluco F (2003) Efeito de fatores bióticos no crescimento de Hypnea musciformis (Rhodophyta - Gigartinales). Acta Botanica Brasilica 17:279-286

Rindi L, Bello MD, Dai L, Gore J, Benedetti-Cecchi L (2017) Direct observation of increasing recovery length before collapse of a marine benthic ecosystem. Nature Ecology and Evolution 1:1-7

Rodríguez-Martínez RE, Medina-Valmaseda AE, Blanchon P, Monroy-Velázquez L V., Almazán-Becerril A, Delgado-Pech B, Vásquez-Yeomans L, Francisco V, García-Rivas MC (2019) Faunal mortality associated with massive beaching and decomposition of pelagic Sargassum. Marine Pollution Bulletin 146:201-205

Salvaterra T, Green DS, Crowe TP, O’Gorman EJ (2013) Impacts of the invasive alga Sargassum muticum on ecosystem functioning and food web structure. Biological Invasions 15:2563-2576

Schiel DR, Lilley SA (2011) Impacts and negative feedbacks in community recovery over eight years following removal of habitat-forming macroalgae. Journal of Experimental Marine Biology and Ecology 407:108115

Schmidt AL, Scheibling RE (2007) Effects of native and invasive macroalgal canopies on composition and abundance of mobile benthic macrofauna and turf-forming algae. Journal of Experimental Marine Biology and Ecology 341:110-130

Stæhr PA, Pedersen MF, Thomsen MS, Wernberg T, Krause-Jensen D (2000) Invasion of Sargassum muticum in Limfjorden (Denmark) and its possible impact on the indigenous macroalgal community. Marine Ecology Progress Series 207:79-88

Strain EM, Thomson RJ, Micheli F, Mancuso FP, Airoldi L (2014) Identifying the interacting roles of stressors in driving the global loss of canopy-forming to mat-forming algae in marine ecosystems. Global Change Biology 20(11):3300-3312

Strong JA, Dring MJ, Maggs CA (2006) Colonisation and modification of soft substratum habitats by the invasive macroalga Sargassum muticum. Marine Ecology Progress Series 321:87-97

Széchy MD, Galliez M, Marconi MI (2006) Quantitative variables applied to phenological studies of Sargassum vulgare c. Agardh (phaeophyceae-Fucales) from ilha grande Bay, state of Rio de Janeiro. Brazilian Journal of Botany 29(1): 27-37

Tait LW,Schiel DR (2011) Legacy effects of canopy disturbance on ecosystem functioning in macroalgal assemblages. PLOS one 6(10) e26986

Tano S, Eggertsen M, Wikström SA, Berkström C, Buriyo AS, Halling C (2016) Tropical seaweed beds are important habitats for mobile invertebrate epifauna. Estuarine, Coastal and Shelf Science 183: 1-12 
van Tussenbroek BI, Hernández Arana HA, Rodríguez-Martínez RE, Espinoza-Avalos J, Canizales-Flores HM, González-Godoy CE, Barba-Santos MG, Vega-Zepeda A, Collado-Vides L (2017) Severe impacts of brown tides caused by Sargassum spp. on near-shore Caribbean seagrass communities. Marine Pollution Bulletin 122:272-281

Vásquez JA, Zuñiga S, Tala F, Piaget N, Rodríguez DC, Vega JMA (2013) Economic valuation of kelp forests in northern Chile: values of goods and services of the ecosystem. Journal of Applied Phycology 26:10811088

Wernberg T, Connell SD (2008) Physical disturbance and subtidal habitat structure on open rocky coasts: Effects of wave exposure, extent and intensity. Journal of Sea Research 59:237-248

Wikström SA, Kautsky L (2007) Structure and diversity of invertebrate communities in the presence and absence of canopy-forming Fucus vesiculosus in the Baltic Sea. Estuarine, Coastal and Shelf Science 72(1): 168-176 


\section{Main Objectives}

Here, the assemblages of mobile invertebrates associated to algal canopies and turfs are formally compared, and the temporal organization of canopy invertebrates at the seasonal Sargassum habitat is assessed with reference to the baseline turf pattern. By doing so, we assessed the potential for algal canopies to enhance the local diversity of small mobile invertebrates, and thus the supply of trophic resources to water-column consumers. We specifically asked:

(i) Is variation among functional macroalgal types more important than variation within canopies or turf types?

(ii) Are canopies actually capable to add additional invertebrate groups to the standard invertebrate assemblage found at less complex turf habitats?

(iii) Do any differences among these vegetated habitats include the abundance of valuable prey for pelagic consumers, thus affecting whole ecosystem functioning?

(iv) Do Sargassum-dwelling invertebrate assemblages actually drift away from the turf baseline as the canopy-blooming season advance?

(v) Are seasonal communities associated to Sargassum controlled by foundation (i.e. compatible with stochastic and site-specific lottery dynamics, in which founder species influence succession) or by dominance (i.e. leading to more predictable and consistent ecological succession)? 


\title{
Chapter 1. Ecosystem functioning of canopy and turf-forming algae: potential supply of invertebrate prey to pelagic consumers
}

Running page head: Invertebrates associated to canopies and turfs

Carla K. Figueiredo ${ }^{1,2}$, Rafael Campos Duarte ${ }^{3}$, Augusto A. V. Flores ${ }^{1 *}$

1. Center for Marine Biology - University of São Paulo, São Sebastião, SP, Brazil

2. Department of Biology - Faculty of Philosophy, Science and Letters of Ribeirão Preto.

University of São Paulo, Ribeirão Preto, SP, Brazil

3. Federal University of ABC-São Bernardo do Campo, SP, Brazil

*Corresponding author: guca@usp.br; +55 1238628415

\begin{abstract}
Canopy-forming algae may provide trophic resources and structural complexity for a wide array of mobile invertebrates, which in turn may sustain pelagic consumers of higher trophic levels. However, algal canopies are declining worldwide and replaced by less-complex macroalgal turfs which may dominate reefscapes. Here, we first compare the assemblages of mobile invertebrates associated to main canopy-forming (Sargassum spp. and Galaxaura marginata) and turf-forming algae (filamentous and articulated coralline turf), and then assess if, and how, canopy-dwelling invertebrate assemblages drift away from the turf baseline during the blooming season of the main canopy habitat (Sargassum). Abundance, biomass and diversity almost always differed between canopies and turfs at sampling sites, while differences within main functional algal types were nearly absent. But, surprisingly, none of those overall metrics varied in any consistent way across sampling sites. Differently, the assemblage structure consistently differed between canopies and turfs, with hardbodied (as gastropods and brachyuran crabs), and soft-bodied (mainly polychaetes and flatworms) invertebrates characterizing canopy and turf assemblages, respectively. The divergence between invertebrate assemblages at canopies and turfs increased as the canopy-blooming season advanced. Notably, while the invertebrate assemblage structure remained unaltered at turfs, early-successional brittle stars and amphipods were followed by hard-shelled gastropods, bivalves and ostracods in Sargassum, where they become dominant and decreased diversity later on within the season. As hardshelled prey are preferred items for the main invertivore fish species in the area, results indicate that canopies play a particularly important role in the provisioning of trophic resources to pelagic consumers.
\end{abstract}

Keywords: ecosystem engineering, phase-shifts, competition, ecological succession, reef fish 


\section{Introduction}

Reef macroalgae may often grow to canopy height and thus play unique ecosystem functions. As such, canopy-forming algae are considered 'ecosystem engineers', influencing important environmental factors within the reef habitat. As physical barriers to flow over the substrate, large macroalgae may change local hydrodynamics, thereby protecting coastlines by reducing coastal surge, and retaining large quantities of sediments that host diverse biological assemblages (Eriksson et al. 2006, Schmidt \& Scheibling 2007). As important primary producers, algal canopies contribute to nutrient uptake, carbon sequestration and ultimately climate control (Schmidt \& Scheibling 2007, Filbee-Dexter \& Wernberg 2018, Piazzi et al. 2018). Macroalgal beds also sustain additional loops to coastal trophic webs, directly sustaining different herbivores, from large browsers to grazers spanning 2-3 orders of magnitude in size (e.g. Estes \& Duggins 1995, Hughes et al. 2007), providing particulate matter for filter-feeding invertebrates (Heip et al. 1995, Vizzini \& Mazzola 2003), and small planktivores (Vizzini \& Mazzola 2003, Metillo et al. 2016), and subsidizing terrestrial trophic webs after being detached from the substrate after storms and deposited along shorelines (Adin \& Riera 2003, MacMillan \& Quijón 2012).

Canopy-forming algae also add physical complexity to seascapes, hosting not only the herbivores that directly feed on plant tissues, but also a very diverse and abundant fauna of mobile benthic invertebrates that locally prey on first-order consumers and find shelter on the intricate structure formed by algal branches (Wikstrom \& Kautsky 2007, Tait \& Schiel 2011, Matias et al. 2015, Filbee-Dexter et al. 2016). This partially self-contained biological assemblage may in turn sustain larger demersal carnivores, linking benthic primary production to higher-order trophic levels in the pelagic ecosystem (Strain et al. 2014, Tano et al. 2016, Filbee-Dexter \& Wernberg 2018). Still, this important benthic-pelagic coupling may be highly vulnerable to environmental disturbance because canopy-forming algae are generally late successional species, competing with the physically impoverished vegetated substrates formed by filamentous and articulated coralline turf ( $\mathrm{O}$ 'Brien \& Scheibling 2018). The phase-shift between a state of habitat complexity, with the predominance of canopy-forming algae, to a poorer state, in which algal turfs prevail, has been repeatedly linked to different sources of anthropogenic impact (Benedetti-Cecchi et al. 2001, Airoldi et al. 2008, Gorman \& Connel 2009, Perkol-Finkel \& Airoldi 2010), including the concentration of heavy metals, excessive sedimentation from coastal runoff, overfishing and eutrophication (Strain et al. 2014), as well as climate change, through ocean heat-waves and storms (Filbee-Dexter \& Wernberg 2018). Competition with more opportunistic seaweeds (Schmidt \& Scheibling 2007, Reeves et al. 2018, Lutz et al. 2019) may further contribute to the worldwide decline of temperate macroalgal canopies, notably large fucoids (Wikstrom \& Kautsky 2007, Connel \& Russel 2010), which have been mostly replaced by turf-forming algae, leading to impoverished landscapes (Airoldi et al. 2008, Gorman et 
al. 2009). Once established, algal turfs most often reduce the recruitment rate of canopy-forming algae through space preemption and sediment accumulation, making it an unstable substrate for settlement (Bellgrove et al. 2010, Alestra et al. 2014, O’Brien \& Scheibling 2018).

Turf-to-canopy dynamics are much less understood in tropical systems, where canopyforming algae are more diversified and relatively smaller. One important group, however, are brown algae of the genus Sargassum C. Agardh, 1820. In the subtropical Southwestern Atlantic, Sargassum spp. is very abundant on rocky reefs (Paula \& Eston 1987, Széchy \& Paula 2000a, Jacobucci et al. 2019), encompassing 13 different species (de Paula 1988). Altogether, their abundance is highly seasonal, peaking in summer and decaying shortly after, sometimes to virtual absence during winter (Godoy \& Coutinho 2002, Széchy et al. 2006). Several studies have described the spatial distribution patterns of Sargassum, and the rich fauna associated to this brown weed (e.g. Széchy \& Paula 2000a, Godoy \& Coutinho 2002, Jacobucci \& Leite 2006, Mafra \& Cunha 2006, Marinho-Soriano et al. 2006, Bertagnolli et al. 2014), overall suggesting that Sargassum beds serve as a nursery habitat for several invertebrates and fish, and a foraging ground for pelagic consumers, by delivering valuable and diversified prey. However, the relative importance of the seasonal Sargassum canopy remains unclear because no studies have assessed how the invertebrate assemblages associated to this seaweed compare to those inhabiting other algal canopies, or other important vegetated substrates lacking a complex physical structure (i.e. algal turfs). Owing to its seasonal nature, with full developing fronds lasting only 2-4 months, understanding the temporal organization of mobile invertebrate assemblages in Sargassum beds is crucial to assess the importance of this habitat as foraging grounds for pelagic consumers. Because the diversity of benthic mobile invertebrates potentially colonizing algal canopies is immense, the determination of founder invertebrate groups, and hence later assemblage dynamics, may be uncertain and very context-dependent (e.g. lottery models; Sale 1978, Green \& Schoener 1982). Alternatively, early successional invertebrates may be more predictably replaced by superior competitors, which tend to become dominant and endure for longer in the assemblage, following a pattern of ecological succession as observed in other reef systems (e.g. Lubchenco \& Menge 1978, Benedetti-Cecchi 2000). This would narrow down possibilities and allow an anticipation of temporal dynamics, even for very complex and diverse assemblages such as the ones we address here. Understanding whether the temporal dynamics of invertebrate assemblages are founder or dominance-controlled (sensu Yodzis 1986) is thus paramount to assess the role of Sargassum spp. beds, which are declining in the region over the last 40 years (Gorman et al. submitted), and their blooming seasons probably shortening.

Here we first compare the mobile invertebrate assemblages associated to canopy-forming algae [Sargassum spp. and Galaxaura marginata (Kützing)] and algal turfs (filamentous and coralline) to assess the capacity of those vegetated habitats to host abundant and diversified 
communities. Namely, we asked (i) whether variation among functional macroalgal types is more important than variation within canopies or turf types, (ii) whether canopies are actually capable to add additional invertebrate groups to the standard invertebrate assemblage found at less complex turf habitats, and (iii) whether any differences found among these vegetated habitats include the abundance of valuable prey for pelagic consumers, thus affecting whole ecosystem functioning. Second, we compare the temporal dynamics of the invertebrate assemblages associated to Sargassum beds and filamentous turfs to (iv) test whether the invertebrate assemblages at Sargassum actually drift away from the turf baseline as the canopy-blooming season advances, and, according to Yodzis (1986), (v) test whether the seasonal communities associated to Sargassum are foundation controlled (i.e. compatible with a stochastic and site-specific lottery dynamics, in which founder species influence succession) or dominance controlled (i.e. leading to more predictable and consistent ecological succession). The underlying mechanisms controlling the temporal dynamics of invertebrate assemblages at Sargassum would ultimately determine whether maximum ecosystem functioning can be achieved before its seasonal decay.

\section{Material and Methods}

Study site

Three sites were sampled along the São Sebastião Channel (SSC) on the northern coast of São Paulo State, Brazil (Guaecá: 23.822 S, 45.468 W, Pedra Montada: 23.829 S, 45.442 W, and Zimbro: 23.825 $\mathrm{S}, 45.420 \mathrm{~W}$ ), comprising a coastline of approximately $4 \mathrm{~km}$. This is a generally sheltered coastline, with the rocky shores at Guaecá and Pedra Montada closer to the Southwestern SSC end, but facing East, and thus protected from direct swell, and Zimbro further into the mid-section of the channel and facing south. From late spring to early autumn, shallow underwater reef habitats, such as those found at the selected sampling sites, are extensively covered by macroalgae of two different functional types; turfs and canopy-forming algae. Turfs can be broadly separated in those formed mostly by filamentous (hereafter "filamentous turf") or articulated coralline algae ("coralline algal turf'). Several different species may build canopy habitat for several different invertebrates and fish recruits, but the brown weed Sargassum spp. and the red alga Galaxaura marginata are particularly common at the study sites and were thus target of this study. Reduced wave action usually favors the vertical growth of algal canopies, especially Sargassum (Széchy et al. 2006, Veloso e Széchy 2008), and therefore algal canopies at the study sites are expected to be more luxurious than average in the region. 
Field sampling

This study is divided in two main tasks; the first to compare invertebrate assemblages associated to algal turfs and canopies, and test whether those algal substrates can be considered single functional habitats, and the second to verify whether canopy-specific invertebrates assembly in any predictable temporal way during the blooming season of Sargassum.

Canopy vs turf comparisons - Fieldwork for the first task took place between December 2017 to March 2018, when the Sargassum cover is high and their fronds well-developed. At all three sites, four replicate samples were taken for each of four algal substrates; 2 canopy-forming algae (Sargassum spp. and Galaxaura marginata) and 2 algal turf types (filamentous and coralline) at shallow depth (1-5 m below mean low-tide level). Sampling units consisted of all macroalgal materials scrapped within $40 \times 40 \mathrm{~cm}$ PVC squares, placed at separate (at least $5 \mathrm{~m}$ ) and interspersed random patches of full canopy or turf cover $(100 \%)$. As macroalgae were scraped off the substrate, a $38 \mathrm{~mm}$ hose connected to a $5.5 \mathrm{HP}$ pump onboard (set at $12 \mathrm{~m}^{3} \cdot \mathrm{h}^{-1}$ ) suctioned all materials to a net bag $(150 \mu \mathrm{m})$. All underwater work was undertaken using SCUBA. Sample bags were immersed onboard on large plastic buckets and immediately sorted out upon arrival to the laboratory.

Temporal assembly of invertebrates associated to canopy-forming algae - This task was divided in two stages. First we reported the seasonal variation of algal canopies formed by Sargassum spp. and Galaxaura marginata by monthly sampling all three sites from October 2014 to July 2015. At each site and sampling date, video footage was taken along a $70 \mathrm{~m}$ ruled transect, laid parallel to the shoreline at the depth of maximum canopy cover, to allow a record of virtually all canopy cover. Fifteen replicate frames were randomly sampled out from each footage to obtain estimates of abundance (percentage cover) on ImageJ (Rasband 1997). The average area covered by each frame was $1.902 \mathrm{~m}^{2}$, but there was considerable variation among sites and sampling dates (overall $\mathrm{SD}=$ $1.216 \mathrm{~m}^{2}$ ) owing to several environmental conditions, such as tide level, visibility and the extent of the long-shore canopy width. The second stage of this temporal sampling task aimed the identification of any assembly patterns during the development of seasonal algal canopies (Sargassum) that drifted invertebrate assemblages away from the turf baseline. For that, we obtain four replicate samples of Sargassum spp. and filamentous turf at Pedra Montada and Zimbro during three different moments within the main canopy season (December 2018, January and February 2019). The sampling procedure followed exactly the one described above. 
Laboratory procedures

The contents of mesh bags were immediately placed in large buckets, washed and vigorously shaken. Suspended materials were then sieved and retained in a 1-mm mesh sieve. The whole procedure was repeated several times until invertebrates were no longer found on sieves. Sampled materials were then re-suspended in seawater and sorted through a sequence of sieves of decreasing mesh size (12.5; $8.0 ; 6.3 ; 4.0 ; 2.8 ; 1.7$ and $1.2 \mathrm{~mm})$. The contents of each sieve were washed and rinsed into white plastic trays, and invertebrates were sorted out and preserved in $70 \%$ ethanol. The thickness of filamentous and coralline turf was fairly constant across sites and sampling dates $(1-2 \mathrm{~cm})$ but the thallus length of canopy-forming macroalgae was highly variable. We thus measured the length of separate five random fronds within each Sargassum and Galaxaura sample to verify whether canopy height (a measure of structural complexity) may eventually affect overall metrics of invertebrate assemblages. All invertebrates were identified into large taxonomic groups (within a total of 29) and counted under a dissecting microscope.

\section{Statistical analyses}

Canopy vs turf comparisons - One-way omnibus general linear models were used to test whether invertebrate assemblages differed between canopy-forming algae and algal turfs, and whether differences are also found within these major habitat types. For that, we used mean square error estimates obtained from the main procedure to test the three respective planned contrasts, namely (i) canopy vs turf (Sargassum - Galaxaura vs filamentous turf - coralline turf), (ii) within canopies (Sargassum vs Galaxaura), and (iii) within turfs (filamentous turf vs coralline turf). Dependent univariate metrics included overall abundance, the Shannon-Wiener $\left(H^{\prime}\right)$ diversity index, average size and overall biomass (using the size-to-weight relationship obtained by Méthot et al. 2012). Data were square-root transformed when needed to meet variance homogeneity. The same model was used to examine assemblage structure but, as a multivariate variable, permutational analyses of variance on square-root transformed data (singletons removed) were run instead, using type I sums of squares and unrestricted permutation (9,999 times) of raw data. Pairwise comparisons followed the same contrasts above, and similarity percentage analyses were conducted, whenever comparisons proved significant, to identify the taxonomic groups that contributed the most for dissimilarities.

Seasonal cover of canopy-forming algae - In order to test whether canopy-forming algae are seasonal, and whether seasonality varied somehow among sampling sites, separate 2-way general linear mixed models were run to analyze the percent cover of each algal species (Sargassum spp. and Galaxaura marginata), according to 'site' (random) and 'month' (fixed), using 15 replicate observations. The 
arc-sin transformation solved heteroscedasticity for Sargassum, but not Galaxaura. Still, we maintained the original procedure as datasets were balanced and replication was high (Underwood 1997). The SNK procedure was used for post-hoc comparisons among months.

Temporal assembly of invertebrates - Three-way general linear mixed models, with factors 'alga' (fixed, with levels 'Sargassum' and 'filamentous turf'), 'time' (fixed, with levels 'December', 'January' and 'February'), and 'site' (random, with levels 'Pedra Montada' and 'Zimbro') were used to examine the invertebrate assemblage metrics specified above. Statistical significance of the twoorder interaction 'alga*time', would indicate habitat-dependent temporal change of invertebrate community structure, as predicted, while significance of the tree-order interaction 'alga*time*site', would also point to divergent assembly of invertebrate groups between algal types, with drifting patterns, however, dependent on idiosyncratic conditions at sampled sites. Equivalent permutational analyses of variance were carried out to examine invertebrate assemblage structure, as above. Planned contrasts were restricted to $\mathrm{t} 1 \mathrm{vs} \mathrm{t} 2$ (December vs January) and $\mathrm{t} 2 \mathrm{vs} \mathrm{t} 3$ (January vs February), either for different 'algal' types, or within level combinations of 'alga*site'. 


\section{Results}

\section{Canopy vs turf comparisons}

A total of 39,987 specimens, 23,321 from canopies and 16,666 from turfs, encompassing 29 major invertebrate groups (details in Table S1), were recorded. All univariate metrics, except for average individual size, responding only to site effects (Table 1), indicate significant differences of invertebrate assemblages associated to the sampled algal habitats. However, differences were not consistent across sites as indicated by the significant interaction between factors 'alga' and 'site' (Table 1). Overall, planned comparisons indicated that differences between algal types, i.e. canopy vs turf, significant in 8 out of 9 comparisons, were far more important than differences between different canopies (Sargassum vs Galaxaura) or between turf-forming algae (filamentous vs coralline), which were only significant in 1 out 18 occasions (Fig. 1).

Table 1. Summary results of general linear mixed models comparing main parameters of invertebrate assemblages associated to algal canopies (Sargassum spp., Galaxaura marginata) and turfs (filamentous and coralline). $C$ : Cochran's statistic testing for variance heterogeneity. $P$-values in bold indicate statistical significance of relevant sources of variation.

\begin{tabular}{|c|c|c|c|c|c|c|c|c|c|c|c|}
\hline & \multirow[b]{3}{*}{$d f$} & \multicolumn{10}{|c|}{ Canopy vs Turf } \\
\hline & & \multicolumn{2}{|c|}{ Abundance } & \multicolumn{2}{|c|}{ Diversity } & \multicolumn{2}{|c|}{ Biomass } & \multicolumn{2}{|c|}{ Average size } & \multicolumn{2}{|c|}{ Structure } \\
\hline & & $F$ & $P$ & $F$ & $P$ & $F$ & $p$ & $F$ & $p$ & $\begin{array}{c}\text { pseudo- } \\
\text { F }\end{array}$ & $p$ \\
\hline $\begin{array}{l}\text { Alga: } \\
\text { Al }\end{array}$ & 3 & 1.12 & 0.413 & 1.11 & 0.415 & 0.39 & 0.767 & 3.48 & 0.091 & 8.49 & 0.001 \\
\hline Site: $\mathrm{Si}$ & 2 & 4.59 & 0.017 & 4.37 & 0.020 & 10.05 & $<0.001$ & 4.57 & 0.017 & 7.68 & 0.001 \\
\hline $\mathrm{Al} * \mathrm{Si}$ & 6 & 4.24 & 0.003 & 3.47 & 0.008 & 2.69 & 0.0294 & 1.01 & 0.437 & 2.97 & 0.001 \\
\hline \multirow[t]{2}{*}{ Res. } & 36 & \multirow{2}{*}{\multicolumn{2}{|c|}{$\begin{array}{c}\sqrt{\mathrm{x}} \text { transf. } \\
C=0.2737 ; p>0.05\end{array}$}} & & & & & & & & \\
\hline & & & & \multicolumn{2}{|c|}{$\begin{array}{l}\text { Raw data } \\
C=0.1460 ; p>0.05\end{array}$} & \multicolumn{2}{|c|}{$\begin{array}{c}\sqrt{\mathrm{x}} \text { transf. } \\
C=0.2144 ; p>0.05\end{array}$} & \multicolumn{2}{|c|}{$\begin{array}{c}\sqrt{\mathrm{x}} \text { transf. } \\
C=0.3967 ; p<0.01\end{array}$} & \multicolumn{2}{|c|}{$\begin{array}{c}\sqrt{\mathrm{x}} \text { transformed } \\
-\end{array}$} \\
\hline
\end{tabular}

However, metrics were much less favorable to canopy-forming algae than anticipated. Abundance (Fig. 1 A-C) and biomass (Fig. 1 D-F) were higher for canopies at Zimbro (Fig. 1 C, F) and Pedra Montada (Fig. 1 B, E), but higher for turfs at Guaecá (Fig. 1 A, D; alhough not significant for abundance, Fig. 1A). The trends for diversity are actually more favorable to algal turfs (Fig. 1 GI). Average Shannon-Wiener diversity was higher for turf assemblages at Guaecá (Fig. 1G) and Pedra Montada (Fig. 1H), but not at Zimbro (Fig. 1I), where diversity for canopy assemblages was slightly (but significantly) higher for canopy assemblages. Contrasts of invertebrates assemblages within any algal functional type were restricted to canopies at Zimbro, where overall abundance was almost 
2-fold higher at Galaxaura compared fo Sargassum. Although with average frond size varying from 5 to $18 \mathrm{~cm}$ for Sargassum, and 5 to $14 \mathrm{~cm}$ for Galaxaura, no correlation was observed between any of the tested parameters and canopy height $(0.03<r<0.34 ; p>0.30$ in all cases; Fig. S1), suggesting that additional complexity, such as surface plant area and whole interstitial volume, did not affect assemblages in any obvious way.

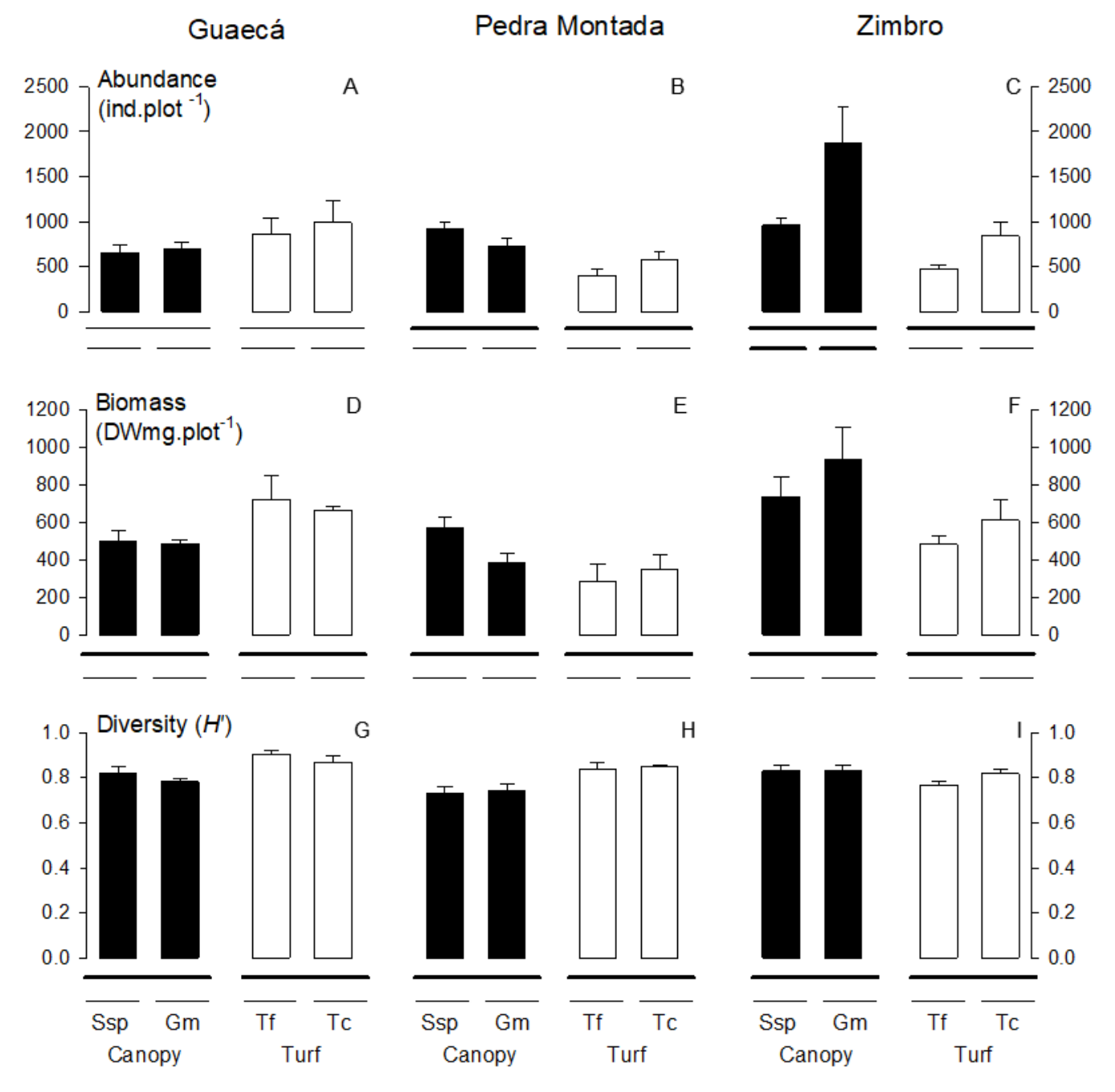

Fig. 1. Comparisons of univariate descriptors of invertebrate assemblages between and within macroalgal habitat types at sampling sites (A-I). Columns and error bars represent average values and respective SEs. Ssp: Sargassum spp., Gm: Galaxaura marginata, Tf: Filamentous turf, Tc: Coralline turf. Significance planned comparisons $(p<0.05)$ are indicated with bold underlines. 
The invertebrate assemblage structure between algal substrates was markedly different at all sampling sites (Table 1). Planned comparisons showed that sound dissimilarities are almost restricted to canopy vs turf comparisons for all sites $(4.62<$ Pseudo- $F<13.60$; $0.0001<p<0.028$; Fig. 2 AC), with more clear differences at Guaecá and Zimbro (overall dissimilarities 33.24 and 39.96\%, respectively, Fig. 2A, C), compared to Pedra Montada (28.64\%, Fig. 2B). No differences were ever found between turfs, and differences between canopies were restricted to Pedra Montada (pseudo- $F$ $=2.21, p=0.028$; Fig. 2B). Similarity percentage analyses indicated that six invertebrate groups contributed the most to differences between the assemblage structure of invertebrates at canopies and turfs (Table S2), namely gastropods, polychaetes, brittle stars, tanaids, flat worms and brachyuran crabs (Table S2, Fig. 2 D-F). Not all six contributed to $7 \%$ or more of dissimilarities at sampling sites, with flat worms and brachyuran crabs making only 3.86 and $1.76 \%$, and 3.33 and $5.31 \%$ at Guaecá and Pedra Montada, respectively; and tanaids only 5.67 and 5.77\% at Pedra Montada and Zimbro (Table S2). Still, all these invertebrate groups were considered in further analyses for all sites. The most consistent trend was the much higher abundance of gastropods at canopies than at turfs (Table S1, Fig. 2 D-F), confirmed by $t$-tests for all three sites. Brachyuran crabs were also numerically more abundant at canopies than at turfs at all sites, but this difference was only significant at Zimbro (Fig. 2F). Groups that were otherwise more abundant at turfs than at canopies were polychates and flat worms (with statistical support found at Guaecá for the former, and Guaecá and Zimbro for the latter, Fig. 2 D, F). The abundance variation for the other two groups was more inconsistent, but a statistically significant difference was found at Zimbro for brittle stars (more abundant at canopies, Fig. 2F) and at Guaecá for tanaids (more abundant at turfs, Fig. 2D). The dissimilarities between algal canopies found at Pedra Montada accounted mostly for a higher abundance of gastropods, polychates and tanaids at Sargassum compared to Galaxaura, but no statistical significances were observed for separate comparisons of the abundance of these groups between canopies. 


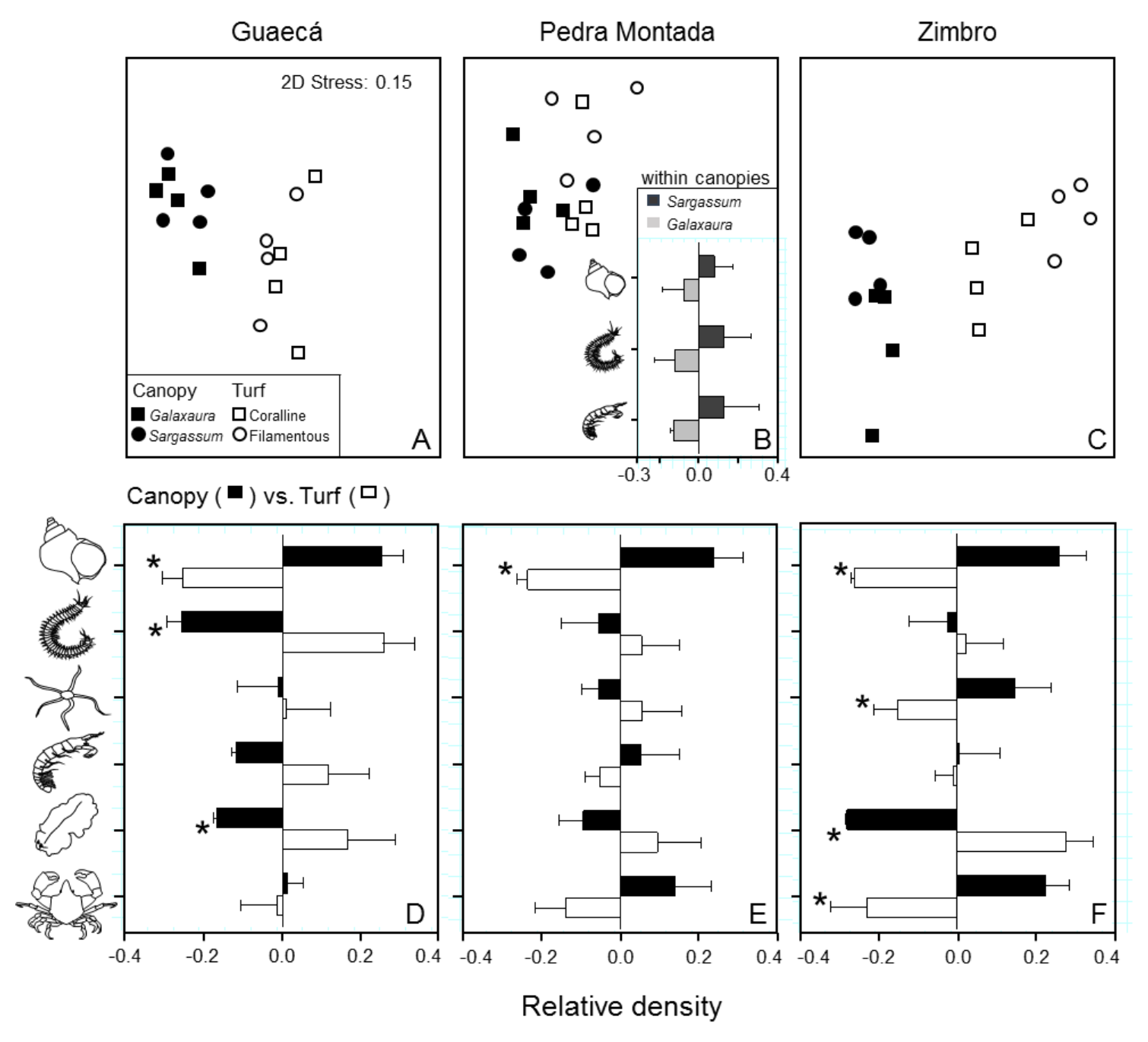

Fig. 2. Comparisons of the invertebrate assemblage structure between and within macroalgal habitat types at sampling sites. Pairwise comparisons after the omnibus permutational analysis of variance indicated significant canopy vs turf contrasts at all sites, and significant contrasts within canopy-forming algae at Pedra Montada (Sargassum vs Galaxaura). A-C: Spatial ordination figures extracted from the whole-data nMDS plot showing sample clusters at Guaecá, Pedra Montada and Zimbro. The average relative densities of invertebrate groups contributing the most for dissimilarities between canopy-forming algae (B), and between the pools of canopyforming and turf algae (D-F), were obtained from normalized and mean-subtracted raw data (ind.plot ${ }^{-1}$ ). Drawings represent gastropods, polychaetes, tanaids (B), and gastropods, polychaetes, brittle stars, tanaids, flat worms and brachyuran crabs (D-F) from the upper to the lower end of plots. Error bars stand for 1SE and asterisks indicate cases of statistical significance $(t$ tests, $p<0.05)$. 
Seasonal cover of canopy-forming algae and the assembly of invertebrates

The seasonal cover of Sargassum spp. and Galaxaura were nearly inversely related, especially at Guaecá and Pedra Montada (Fig. 3 A,B). Altogether, the cover of these two canopy-forming algae can make up most available reef habitat in the region, as observed in January at Guaecá (75.4\%) and Pedra Montada (64.2\%), and in December at Zimbro (68.7\%; Fig. 3 A-C). Sargassum spp. reached a much higher cover and showed a clearer seasonal variation compared to Galaxaura at all sites. Strong 'site*month' interactions were found for both canopy-forming weeds (Sargassum: $F_{\mathrm{s}^{*} \mathrm{~m}}=$ 4.48; Galaxaura: $F_{\mathrm{s}^{*} \mathrm{~m}}=5.63 ; p<0.0001$ in both cases; Fig. 3A-C). Sargassum abundance was highest from January to February at Guaecá, December to February at Pedra Montada and December through May at Zimbro (SNK post-hoc tests, $p<0.05$ ). The trend for Galaxaura is less clear, with higher substrate cover from October to November, and then from April to July in Guaecá, and single peak abundances at July and December observed at Pedra montada and Zimbro, respectively (SNK post-hoc tests, $p<0.05$; Fig. 3A-C).

Because the overall abundance was higher and the seasonal trend clearer at Sargassum spp., we used this vegetated habitat to examine the temporal assembly patterns of mobile invertebrates associated to algal canopies, namely from December 2018 to February 2019 (corresponding to the area shaded in grey in Fig. 3). During this period, 19,274 and 28,430 mobile individuals were found associated to Sargassum spp. and filamentous turfs, respectively, encompassing 27 major invertebrate groups (Table S3). 

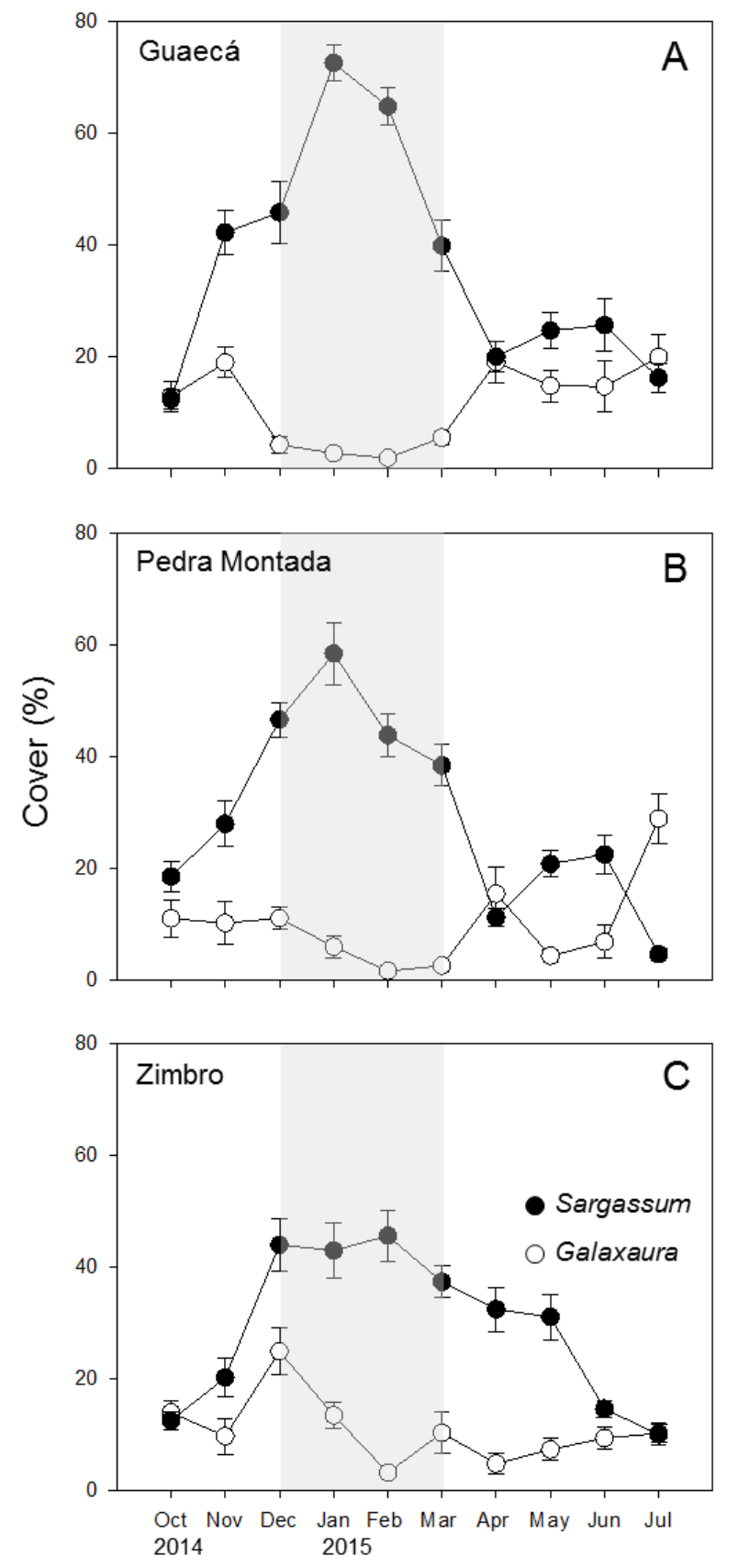

Fig. 3. Seasonal variation of the abundance of canopy-forming algae, as percent cover, at sampling sites Guaecá (A), Pedra Montada (B) and Zimbro (C). The seasonal peak abundance, from December to February, is shown in gray shade. Scatter dots and error bars stand for average values and respective SEs. 
Of all metrics examined in this study, only diversity and assemblage structure showed algal-type dependent temporal trends, although site-specific (as significant three-order interactions 'alga*time*site'; Table 2). Diversity was overall higher at filamentous turfs compared to the Sargassum canopy, but showed quite variable temporal variation depending on algal type and site (Fig. 4). At Pedra Montada, diversity dropped from December to January, and remained low until February in Sargassum (Fig. 4A), but persisted high and stable in filamentous turf (Fig. 4B). At Zimbro, the trends in Sargassum and in filamentous turfs were inversed (Fig. 4 C-D), decreasing in the canopy habitat and increasing in the turf one through time. Statistical differences were only observed between January and February at both sites (SNK post-hoc tests, $p<0.05$ ).

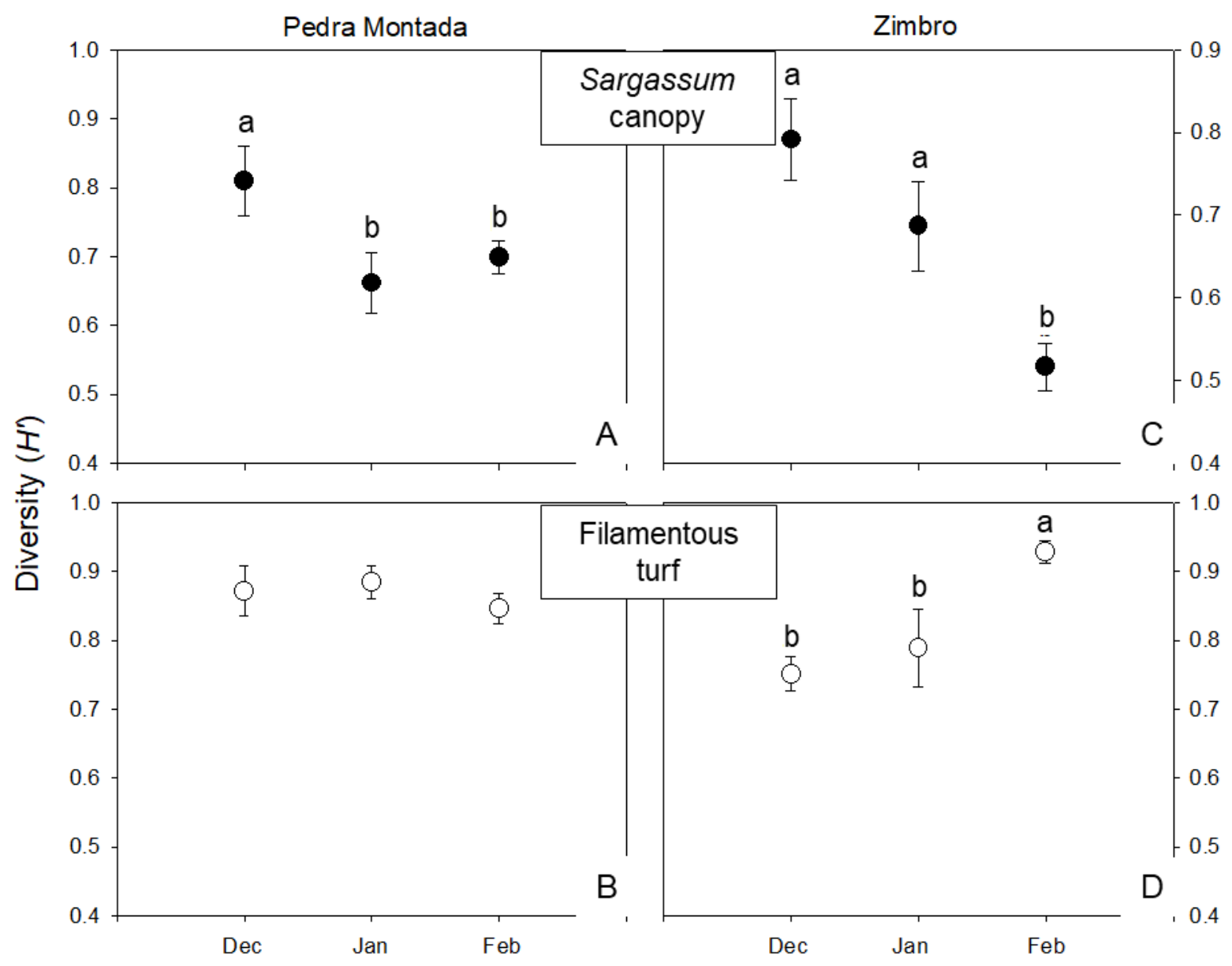

Fig. 4. Shannon-Wiener diversity estimates $\left(H^{\prime}\right)$ for invertebrate assemblages associated to Sargassum canopy and filamentous turf from December 2018 to February 2019 at Pedra Montada (A-B) and Zimbro (C-D). Scatter dots and error bars stand for average values and respective SEs. For each individual plot, diversity estimates sharing the same letter are not statistically different (SNK post-hoc tests, $p>0.05$ ). 
The three-order significant interaction of the model tested through permutational analysis of variance, examining the temporal change of assemblage structure (Table 2), is explained by the observations that (i) temporal changes were restricted to Sargassum spp., but (ii) more extensive at Zimbro, especially from $\mathrm{t} 2$ (January) to $\mathrm{t} 3$ (February; Fig. 5 A-B). In both cases, the invertebrate assemblage structure at Sargassum drifted from the turf baseline through time. Still, the divergence was more pronounced at Zimbro than at Pedra Montada, with overall dissimilarities from $\mathrm{t} 1$ December) to 2 (41.72 compared to $31.48 \%$ ) and from $\mathrm{t} 2$ to $\mathrm{t} 3$ (30.65 compared to $23.76 \%$ ) higher at Zimbro than at Pedra Montada (Table S4, Fig. 5A,B). Pairwise comparisons were however significant for both sites (Zimbro - t1 vs t2: pseudo $F=2.59, p=0.029$; t2 vs t3: pseudo $F=2.43, p$ $=0.030 ;$ Pedra Montada $-\mathrm{t} 1$ vs t2: pseudo $F=1.95, p=0.027$; 2 vs t3: pseudo $F=1.55, p=0.028$ ).

Table 2. Summary results of general linear mixed models comparing main parameters of invertebrate assemblages associated to the algal-forming canopy Sargassum spp. and filamentous turfs over time (December 2018 to February 2019). The random factor 'site' tests the spatial consistency of any divergent patterns characterizing the temporal assembly of major invertebrate groups at the sampled algal habitats. $C$ : Cochran's statistic testing for variance heterogeneity. $P$-values in bold indicate statistical significance of relevant sources of variation.

\begin{tabular}{|c|c|c|c|c|c|c|c|c|c|c|c|}
\hline \multicolumn{12}{|c|}{ Sargassum vs filamentous turf over time } \\
\hline & \multirow[b]{2}{*}{$d f$} & \multicolumn{2}{|c|}{ Abundance } & \multicolumn{2}{|c|}{ Diversity } & \multicolumn{2}{|c|}{ Biomass } & \multicolumn{2}{|c|}{ Average size } & \multicolumn{2}{|c|}{ Structure } \\
\hline & & $\bar{F}$ & $p$ & $F$ & $\bar{p}$ & $F$ & $p$ & $\bar{F}$ & $p$ & Pseudo-F & $p$ \\
\hline $\begin{array}{l}\text { Algal: } \\
\mathrm{Al}\end{array}$ & 1 & 5.19 & 0.263 & 464.31 & 0.030 & 1.00 & 0.500 & 7.52 & 0.223 & 12.80 & 0.170 \\
\hline Time: Ti & 2 & 1.54 & 0.394 & 13.98 & 0.067 & 26.64 & 0.036 & $<0.01$ & 0.999 & 5.10 & 0.015 \\
\hline Site: $\mathrm{Si}$ & 1 & 0.30 & 0.584 & 5.40 & 0.026 & 0.16 & 0.689 & $<0.01$ & 0.964 & 3.33 & 0.017 \\
\hline $\mathrm{Al} * \mathrm{Ti}$ & 2 & 0.39 & 0.719 & 1.54 & 0.394 & 7.15 & 0.123 & 15.88 & 0.059 & 0.93 & 0.534 \\
\hline $\mathrm{Al} * \mathrm{Si}$ & 1 & 1.77 & 0.192 & 0.10 & 0.754 & 3.66 & 0.064 & 2.50 & 0.123 & 2.20 & 0.072 \\
\hline $\mathrm{Ti} * \mathrm{Si}$ & 2 & 1.36 & 0.269 & 0.20 & 0.822 & 0.13 & 0.880 & 2.25 & 0.120 & 2.56 & 0.016 \\
\hline $\mathrm{Al}^{*} \mathrm{Ti} * \mathrm{Si}$ & 2 & 0.41 & 0.669 & 8.07 & 0.001 & 0.54 & 0.587 & 0.92 & 0.408 & 2.11 & 0.043 \\
\hline \multirow[t]{3}{*}{ Res. } & 36 & \multirow{2}{*}{\multicolumn{2}{|c|}{ Raw data }} & & & & & & & & \\
\hline & & & & \multicolumn{2}{|c|}{ Raw data } & \multicolumn{2}{|c|}{ Raw data } & \multicolumn{2}{|c|}{ Raw data } & \multicolumn{2}{|c|}{$\sqrt{x}$ transformed } \\
\hline & & \multicolumn{2}{|c|}{$C=0.2388 ; p>0.05$} & \multicolumn{2}{|c|}{$C=0.1788 ; p>0.05$} & \multicolumn{2}{|c|}{$C=0.2328 ; p>0.05$} & \multicolumn{2}{|c|}{$C=0.2128 ; p>0.05$} & \multicolumn{2}{|l|}{-} \\
\hline
\end{tabular}

Eight different invertebrate groups were found to account for $7 \%$ or more of overall dissimilarities considering all four comparisons, with 4-5 particularly relevant at each specific comparison (Table S4). Wider oscillations of the temporal abundance of those eight invertebrate groups were found at Zimbro (Fig. 5D), but numerical trends are rather consistent between sites. Britlle stars and amphipods were early groups found mostly at $\mathrm{t} 1$ and declining afterwards at $\mathrm{t} 2$ and $\mathrm{t} 3$. This trend is statistically reinforced at Zimbro through separate one-way comparisons, followed by SNK post-hoc tests $(p>0.05)$. Gastropods, bivalves, and ostracods were later groups, with additional statistical 
evidence indicating a steady increase of gastropods at Zimbro, a steady increase of bivalves at Pedra Montada, and a more clear increase of the abundance of bivalves and ostracods from t 2 to 3 at Zimbro (SNK post-hoc tests, $\mathrm{p}>0.05$; Fig. CD). Although contributing to dissimilarities of inverterbrate assemblage structure through time, polychates and hermit crabs did not show temporal variation in any consistent way.
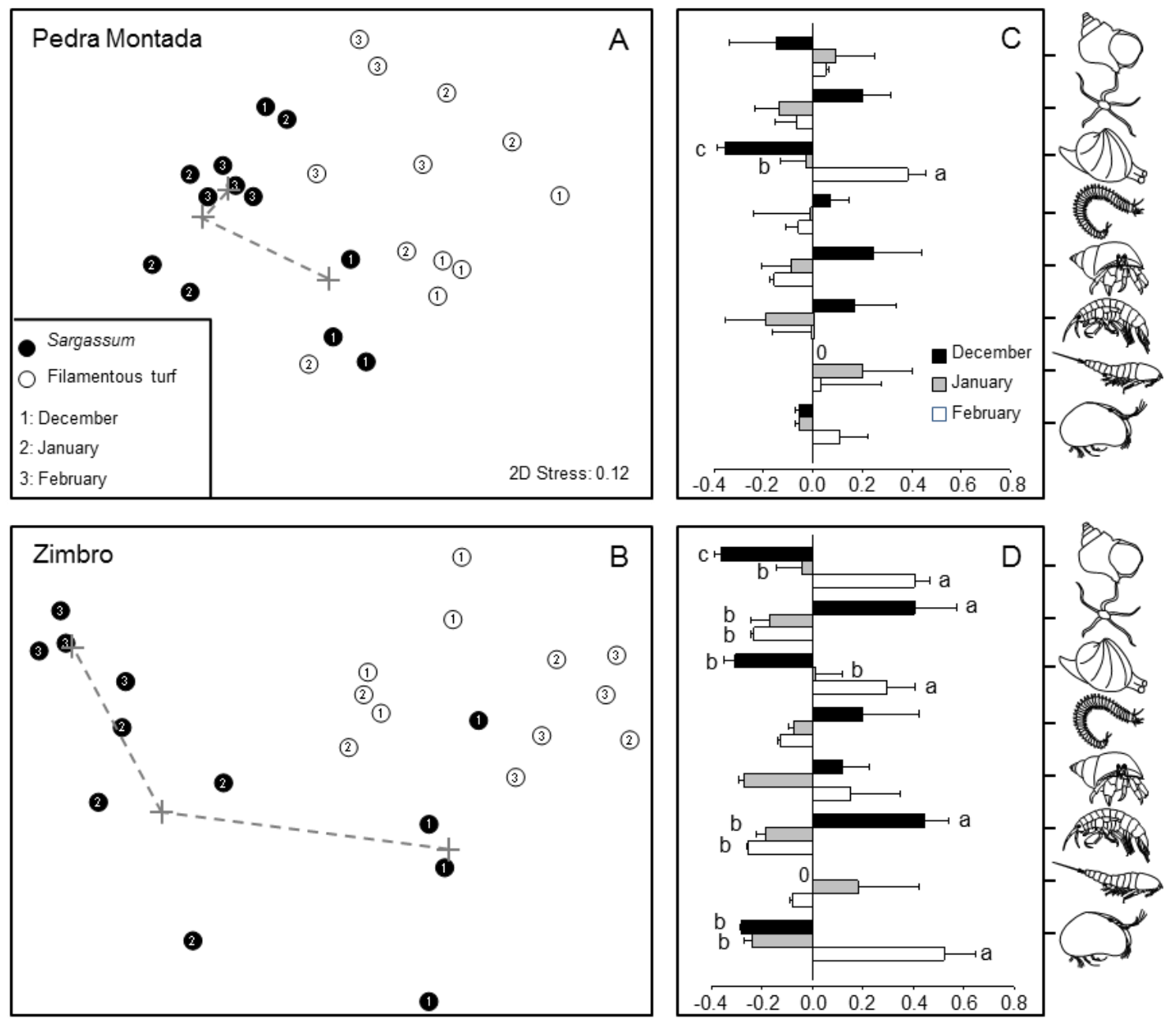

Relative density in Sargassum (ind. plot ${ }^{-1}$ )

Fig. 5. Comparisons of the structure of invertebrate assemblages associated to Sargassum canopies and filamentous turfs at Pedra Montada and Zimbro, from December 2018 to February 2019. A-B: Spatial ordination figures extracted from the whole-data nMDS plot showing sample clusters at $\mathrm{t} 1$ (December), $\mathrm{t} 2$ (January), and $\mathrm{t} 3$ (February) for each site. Planned contrasts evidenced temporal changes of invertebrates assemblage structure at Sargassum canopies but not at filamentous turfs. Assemblage drift from the turf baseline is marked with dashed grey lines connecting centroids at $\mathrm{t} 1, \mathrm{t} 2$ and $\mathrm{t} 3$. C-D: Changes in the relative density of invertebrate groups contributing the most to temporal change. Columns and error bars stand for averages and respective SEs. Relative density estimates sharing the same letter are not statistically different ( $p$ $>0.05$ ). Drawings represent gastropods, brittle stars, bivalves, polychaetes, hermit crabs, amphipods, copepods and ostracods from the upper to the lower end of plots. 


\section{Discussion}

In this study, we show that algal canopies and turfs host clearly different assemblages of mobile invertebrates, while differences within each of these functional algal habitats are much less important. However, differences of overall diversity, abundance and biomass between the mobile fauna found at canopies and turfs were not consistent, and therefore the hypothesis that canopies simply expanded niche space, providing resources for a new set of invertebrate groups, does not hold. While canopies obviously facilitate specific frond-dwelling invertebrate groups, the understory space they provide is, for some reason, apparently not equivalent to the canopy-devoid turf habitat. One possibility is that any invertebrates remaining close to the rock surface will be continuously exposed to the whiplash of canopy fronds (which is absent in turfs), thus reducing the numbers of more vulnerable species and restraining diversity (e.g. Beermann et al. 2013, Petrowski et al. 2016), as observed at Guaecá and Pedra Montada. Otherwise, the lower wave exposure at Zimbro may provide more stable conditions, explaining the larger number of mobile invertebrate groups found thriving in canopy habitats at that site (especially Galaxaura). This mechanism, however, remains uncertain because we had sampled different sites as a means to draw generality of any differences between canopies and turfs, not to test any additional effects of specific environmental conditions. A properly designed study, including replication of sites within different levels of exposure to wave action, would be needed for such a test.

By supplying larger interstitial space among branches (e.g. Gee \& Warwick 1994), we also expected that the average size of invertebrates would be higher in canopy compared to turf-forming algal habitats, but this difference was not observed. Added to the fact that canopy height (a measure of substrate complexity) had also no effect on invertebrate size (not any overall assemblage metric), we conclude that morphological attributes of these vegetated substrates play no major role in determining size-related functional traits. Still, despite the absence of size differences, and the inconsistent variation of diversity, overall abundance and biomass, the assemblage structure of mobile invertebrates was strikingly and rather consistently different between canopies and turfs. Most notably, hard-shelled groups (mostly gastropods and crabs) were more frequently associated to canopy-forming algae, while soft-bodied invertebrates (mainly polychaetes and flatworms) were more abundant in turfs. Resource supply at the sampled habitats may well explain the differences observed on the abundance of these groups. Small gastropods, chiefly the very abundant genera Eulithidium Pilsbry and Bittiolum Cossmann, and specialized canopy-dwelling spider crabs are grazing animals that feed directly on the main algal host or on their epiphytic algae (Hines 1982, Reynolds et al. 2015). Differently, decaying organic particles and interstitial meiofauna in turfretained sediments may be easily accessed by soft-bodied flatworms and polychaetes (e.g. Majdi et al. 2016, Melero et al. 2017), which may easily squeeze amongst sediment grains while foraging, 
giving them a competitive advantage in the turf habitat. In turn, divergent invertebrate assemblages at canopies and turfs may subsidize more diversified pelagic consumers through trophic niche partitioning (e.g. Ross 1986). Since the average size of potential prey is around 2.0 - $3.0 \mathrm{~mm}$, trophic subsidies would more likely impact small cryptobenthic fish species (such as blennies and gobbies; e.g. Depczynski \& Bellwood 2003), or juvenile stages of larger species that use vegetated substrates as nursery grounds. We predict that whether or not those small consumers are able to prey on hardshelled invertebrates may be a critical issue determining the distribution of pelagic consumers over the reef habitat. At our study coastline, some of the most abundant reef fishes are invertivores consuming mobile prey. Five of them are particularly abundant; the grunts Haemulon aurolineatum Cuvier and H. steindachneri (Jordan \& Gilbert), the silver porgy Diplodus argenteus Valenciennes, the sergeant major Abudefduf saxatilis (Linnaeus) and the blenny Parablennius pilicornis (Cuvier) (Gibran \& Moura 2012). Except for the blenny that feeds mostly on polychaetes (Nieder 1997), all other species tend to feed on hard-shelled prey especially during the juvenile phase, as in Haemulon spp., which feed mostly on copepods and amphipods, moving to polychaetes and other fish when they grow to adults (Pereira et al. 2014). Seemingly, the silver porgy feeds mostly on copepods and mussels when juveniles, but shifts to a more omnivorous diet when adults, largely feeding on macroalgae and decapod crustaceans (Dubiaski-Silva \& Masunari 2006). Compared to other damselfishes that are mostly planktivores, Abudefduf spp. feeds mostly on benthic prey (AguilarMedrano \& Barber 2016). The sergeant major A. saxatilis, in particular, is an omnivore, feeding mostly on copepods and filamentous algae during the juvenile phase (Pimentel et al. 2018, Mendonça et al. 2019). We thus conclude that, at the whole-reef level, the combination of canopy and turf habitats may indeed contribute to reef-fish diversity by supplying a wider array of potential invertebrate prey (beyond plant resources, especially turf-forming filamentous algae), but also that algal canopies may be particularly relevant as they supply target prey for a larger fraction of the common invertivores fishes found in the area.

In the study area, Sargassum and Galaxaura combined take, on average, 39 to $48 \%$ of the reef available space throughout the year, reaching together a maximum of 64 to $75 \%$ in December January. Sargassum not only develops to a much taller canopy, but its average cover is nearly 3 -fold that of Galaxaura (varying from 2.72 to 3.17), making it a particularly valuable habitat. However, the Sargassum cover is highly seasonal, and a point was made here that invertebrate assemblages would probably not have the time to reach an equilibrium state, limiting important community traits such as abundance (or carrying support) and diversity, but results do not support this hypothesis. We did confirm that turf assemblages are temporally more stable, that can be used as a reference to evaluate the temporal change of assemblages in Sargassum (as they drifted from the turf baseline as the blooming season advances), but we observed no canopy-specific increases in overall abundance or biomass. More importantly, we had observed an inverse temporal trend of diversity in turfs and 
canopies, especially at Zimbro, with a decline (not an increase) of invertebrate diversity in Sargassum and an increase of diversity in filamentous turfs. Combined, these results indicate that some species had somehow become more dominant at Sargassum through the blooming season, with some spillover of less common groups to turfs. Multivariate analyses during this second part of the study reinforced the notion that hard-shelled invertebrates tend to prevail in canopies, and that assemblage divergences between canopies and turfs become clearer because those invertebrate groups become dominant later on during the Sargassum season, reducing whole-community diversity. Interestingly, the overall temporal dynamics of invertebrate communities at canopies were rather consistent and can be predicted, with peak diversity early in the Sargassum season, sustained in part by a large number of opportunistic species, as brittle stars and amphipods, which later on cease space to other groups (namely gastropods, bivalves and ostracods) that can more efficiently exploit resources and dominate assemblages. The life history and functional ecology of these relevant invertebrate groups explain the observed successional pattern. Most brittle stars in our samples belong to the small invasive species Ophiotela mirabilis Verrill, which is an emblematic generalist, very abundant in the region and colonizing several different biogenic substrata, such as octocorals, sponges, cnidarians, ascidians, echinoderms, algae and bryozoans (Mantelatto et al. 2016). Once established, O. mirabilis can become locally abundant very fast through asexual reproduction (i.e. fission, Tavares et al. 2019), but would hardly compete for space as they do not firmly attach to the substrate or defend themselves by any known means. Likewise, amphipods can locally build up large populations because they are direct-developers, lacking a larval stage, with mothers releasing benthic juvenile individuals (Munguia et al. 2007). However, as very highly mobile organisms, amphipods tend to flee rather than engage in direct competition with more sedentary species (Neideman et al. 2003). Conversely, gastropods (as grazers; Reynolds et al. 2015) and ostracods (as deposit feeders; van Oevelen 2006) tend to remain near their foraging grounds, in the Sargassum case very likely their fronds where very small epiphytic algae and organic debris tend to accumulate as plants get older. Rather than optimizing the use of food resources, filter-feeding bivalves may become dominant because they may effectively clump to each other and remain attached to the substrate by different means, including the production of byssal threads (e.g. Morello et al. 2004, Khalaman \& Lezin 2015).

Like in many other coastal areas, the subtropical SW Atlantic is experiencing the loss of canopy-forming macroalgae at least over the last $40 \mathrm{yr}$. So far, the cover of Sargassum spp. may have shrunk in almost 90\%, while the abundance of other canopy-forming algae (e.g. Galaxaura) may have been reduced in more than $20 \%$ (Gorman et al. in press). This is a very worrying trend because different important ecosystem services - which remain largely unknown - may be at stake. Here we suggest that the coexistence of different algal substrates at any reef site would favor the maintenance of abundant and diversified assemblages of mobile invertebrates, and much probably indirectly benefit several invertivore and omnivore fish species that are abundant in the study area. Owing to 
their local abundance and because they supply reef fish with generally preferred prey types, declines in canopy-forming algae may cascade to serious socio-economic challenges led, for instance, by the collapse of small-scale artisanal fisheries. Conservation policies mitigating the environmental stressors that negatively impact algal canopies, as well as other complex coastal habitats, are therefore urgently needed.

\section{Acknowledgements}

This research was funded by the Coordenação de Aperfeiçoamento de Pessoal de Nível Superior Brasil (CAPES) - Finance Code 001, as a fellowship to CKF, and by the Fundação de Amparo à Pesquisa do Estado de São Paulo (FAPESP), as a research grant (2018/11044-2) to AAVF. The support of CEBIMar staff technicians Joseilto M. de Oliveira and Jerônimo Favaro in the field was invaluable. We sincerely thank them. This is a contribution of the Research Centre for Marine Biodiversity of the University of São Paulo (NPBiomar/USP).

\section{References}

Adin R, Riera P (2003) Preferential food source utilization among stranded macroalgae by Talitrus saltator (Amphipod, Talitridae): a stable isotopes study in the northern coast of Brittany (France). Estuarine Coastal and Shelf Science 56:91-98

Aguilar-Medrano R, Barber PH (2016) Ecomorphological diversification in reef fish of the genus Abudefduf (Percifomes, Pomacentridae). Zoomorphology 135:103-11

Airoldi L, Balata D, Beck MW (2008) The Gray Zone: Relationships between habitat loss and marine diversity and their applications in conservation. Journal of Experimental Marine Biology and Ecology 366:8-15

Alestra T, Tait LW, Schiel DR (2014) Effects of algal turfs and sediment accumulation on replenishment and primary productivity of fucoid assemblages. Marine Ecology Progress Series 511:59-70

Beermann AJ, Ellrich JA, Molis M, Scrosati RA (2013) Effects of seaweed canopies and adult barnacles on barnacle recruitment: The interplay of positive and negative influences. Journal of Experimental Marine Biology and Ecology 448:162-170

Bellgrove A, McKenzie PF, McKenzie JL, Sfiligoj BJ (2010) Restoration of the habitat-forming fucoid alga Hormosira banksii at effluent-affected sites: Competitive exclusion by coralline turfs. Marine Ecology Progress Series 419:47-56

Benedetti-Cecchi L (2000) Predicting direct and indirect interactions during succession in a mid-littoral rocky shore assemblage. Ecological Monographs 70(1):45-72 
Benedetti-Cecchi L, Pannacciulli F, Bulleri F, Moschella PS, Airoldi L, Relini G, Cinelli F (2001) Predicting the consequences of anthropogenic disturbance: Large-scale effects of loss of canopy algae on rocky shores. Marine Ecology Progress Series 214:137-150

Bertagnolli C, Espindola APD, Kleinübing SJ, Tasic L, da Silva MGC (2014) Sargassum filipendula alginate from Brazil: Seasonal influence and characteristics. Carbohydrate polymers 111: 619-623

Connell SD, Russell BD (2010) The direct effects of increasing $\mathrm{CO}_{2}$ and temperature on non-calcifying organisms: increasing the potential for phase shifts in kelp forests. Proceedings of the Royal Society of London B: Biological Sciences 277: 1409-1415

Depczynski M, Bellwood DR (2003) The role of cryptobenthic reef fishes in coral reef trophodynamics. Marine Ecology Progress Series 256:183-191

Dubiaski-Silva J, Masunari S (2006) Ontogenetic and seasonal variation in the diet of marimbá, Diplodus argenteus (Valenciennes, 1830)(Pisces, Sparidae) associated with the beds of Sargassum cymosum C. Agardh, 1820 (Phaeophyta) at Ponta das Garoupas, Bombinhas, Santa Catarina. Journal of Coastal Research, 1190-1192

Eriksson BK, Rubach A, Hillebrand H (2006) Biotic habitat complexity controls species diversity and nutrient effects on net biomass production. Ecology 87:246-254

Estes JA, Duggins DO (1995) Sea otters and kelp forests in Alaska - generality and variation in a community ecological paradigm. Ecological Monographs 65:75-100

Filbee-Dexter K, Feehan CJ, Scheibling RE (2016) Large-scale degradation of a kelp ecosystem in an ocean warming hotspot. Marine Ecology Progress Series 543:141-152

Filbee-Dexter K, Wernberg T (2018) Rise of Turfs: A New Battlefront for Globally Declining Kelp Forests. BioScience 68:64-76

Gee JM, Warwick RM (1994) Metazoan community structure in relation to the fractal dimensions of marine macroalgae. Marine Ecology Progress Series 103:141-150

Gibran FZ, de Moura RL (2012) The structure of rocky reef fish assemblages across a nearshore to coastal islands' gradient in Southeastern Brazil. Neotropical Ichthyology 10:369-382.

Godoy EA, Coutinho R (2002) Can artificial beds of plastic mimics compensate for seasonal absence of natural beds of Sargassum furcatum? ICES Journal of Marine Science 59: S111-S115

Gorman D, Connell SD (2009) Recovering subtidal forests in human-dominated landscapes. Journal of Applied Ecology 46:1258-1265

Gorman D, Russell BD, Connell SD (2009) Land-to-sea connectivity: Linking human-derived terrestrial subsidies to subtidal habitat change on open rocky coasts. Ecological Applications 19:1114-1126

Gorman D, Horta P, Flores AAV, Turra A, Berchez FAS, Batista MB, Lopes Filho ES, Melo MS, Ignacio BL, Carneiro IM, Széchy MTM (Submitted) Decadal losses of canopy-forming algae along the warm temperate. Global Change Biology 
Greene CH, Schoener A (1982) Succession on marine hard substrata: A fixed lottery. Oecologia 55:289-297

Heip CHR, Goosen NK, Herman PMJ, Kromkamp J, Middelburg JJ, Soetaert K (1995) Production and consumption of biological particles in temperate tidal estuaries. Oceanography and Marine Biology 33 : $1-149$

Hines AH (1982) Coexistence in a kelp forest: Size, population dynamics, and resource partitioning in a guild of spider crabs (Brachyura, Majidae). Ecological monographs 52 (2):79-98

Hughes TP, Rodrigues MJ, Bellwood DR, Ceccarelli D, Hoegh-Guldberg O, McCook L, Moltschaniwskyj N, Pratchett MS, Steneck RS, Willis B (2007) Phase shifts, herbivory, and the resilience of coral reefs to climate change. Current Biology 17:360-365

Jacobucci GB, Leite FP (2006) Biologia populacional das espécies de Ampithoidae (Crustacea, Amphipoda) associadas a Sargassum filipendula (Phaeophyta, Fucales) na Praia da Fortaleza, Ubatuba, São Paulo, Brasil. Revista Brasileira de Zoologia 23:1207-1216

Jacobucci GB, Vieira EA, Leite FPP (2019) Influence of a narrow depth gradient on the spatial structure of Sargassum peracarid assemblages in Southeastern Brazil. Marine Biodiversity 49:1001-1011

Khalaman VV, Lezin PA (2015) Clumping behavior and byssus production as strategies for substrate competition in Mytilus edulis. Invertebrate Biology 134:38-47

Lubchenco J, Menge BA (1978) Community development and persistence in a low rocky intertidal zone. Ecological Monographs 48(1): 67-94

Lutz ML, Minchinton TE, Davis AR (2019) Differences in architecture between native and non-indigenous macroalgae influence associations with epifauna. Journal of Experimental Marine Biology and Ecology $514: 76-86$

Mafra Jr LL, Cunha SR (2006) Sargassum cymosum (Phaeophyceae) in southern Brazil: Seasonality of biomass, recovery after harvest and alginate yield. Journal of Coastal Research 39:1861-1866

Majdi N, Kreuzinger-Janik B, Traunspurger W (2016) Effects of flatworm predators on sediment communities and ecosystem functions: a microcosm approach. Hydrobiologia 776:193-207

Mantelatto MC, Vidon LF, Silveira RB, Menegola C, Moreira R, Creed JC (2016) Host species of the nonindigenous brittle star Ophiothela mirabilis (Echinodermata: Ophiuroidea): an invasive generalist in Brazil ? Marine Biodiversity Records:1-7

Marinho-Soriano E, Fonseca PC, Carneiro MAA, Moreira WSC (2006) Seasonal variation in the chemical composition of two tropical seaweeds. Bioresource Technology 97(18):2402-2406

Matias MG, Arenas F, Rubal M, Pinto IS (2015) Macroalgal composition determines the structure of benthic assemblages colonizing fragmented habitats. PloS one 10(11): e0142289

McMillan MR, Quijón PA (2012) Wrack patches and their influence on upper-shore macrofaunal abundance in an Atlantic Canada sandy beach system. Journal of Sea Research 72:28-37 
Melero I, López-Velasco S, López E (2017). On the role of turf species as refuge in disturbed environments: A case study with polychaetes (Annelida: Polychaeta) in SW Mediterranean Sea. Mediterranean Marine Science 18(2):229-240

Mendonça V, Flores AAV, Silva ACF, Vinagre C (2019) Do marine fish juveniles use intertidal tide pools as feeding grounds? Estuarine, Coastal and Shelf Science 225:106255

Metillo EB, Cadelinia EE, Hayashizaki K, Tsunoda T, Nishida S (2016) Feeding ecology of two sympatric species of Acetes (Decapoda: Sergestidae) in Panguil Bay, the Philippines. Marine and Freshwater Research 67:1420-1433

Méthot G, Hudon C, Gagnon P, Pinel-Alloul B, Armellin A, Poirier AMT (2012) Macroinvertebrate size-mass relationships: how specific should they be? Freshwater Science 31:750-764

Morello EB, Solustri C, Froglia C (2004) The alien bivalve Anadara demiri (Arcidae): A new invader of the Adriatic Sea, Italy. Journal of the Marine Biological Association of the United Kingdom 84:1057-1064

Munguia P, Mackie C, Levitan DR (2007) The influence of stage-dependent dispersal on the population dynamics of three amphipod species. Oecologia 153:533-541

Neideman R, Wenngren J, Ólafsson E (2003) Competition between the introduced polychaete Marenzelleria sp. and the native amphipod Monoporeia affinis in Baltic soft bottoms. Marine Ecology Progress Series 264:49-55

Nieder J (1997) Seasonal variation in feeding patterns and food niche overlap in the mediterranean blennies Scartella cristata, Parablennius pilicornis and Lipophrys trigloides (Pisces: Blenniidae). Marine Ecology 18:227-237

O'Brien JM, Scheibling RE (2018) Turf wars: Competition between foundation and turf-forming species on temperate and tropical reefs and its role in regime shifts. Marine Ecology Progress Series 590:1-17

Paula ED, Eston VR (1987) Are there other Sargassum species potentially as invasive as S. muticum? Botanica Marina 30(5): 405-410

Pereira PHC, Barros B, Zemoi R, Ferreira BP (2014) Ontogenetic diet changes and food partitioning of Haemulon spp. coral reef fishes, with a review of the genus diet. Reviews in Fish Biology and Fisheries 25:245-260

Perkol-Finkel S, Airoldi L (2010) Loss and recovery potential of marine habitats: An experimental study of factors maintaining resilience in subtidal algal forests at the Adriatic Sea. PLoS one 5(5) e10791

Petrowski S, Molis M, Bender A, Buschbaum C (2016) Disturbance effects of kelp thalli on structure and diversity of a coastal Arctic marine soft-bottom assemblage. Polar Biology 39:2131-2140

Piazzi L, Bonaviri C, Castelli A, Ceccherelli G, Costa G, Curini-Galletti M, Langeneck J, Manconi R, Montefalcone M, Pipitone C, Rosso A, Pinna S (2018) Biodiversity in canopy-forming algae: Structure and spatial variability of the Mediterranean Cystoseira assemblages. Estuarine, Coastal and Shelf Science 207:132-141 
Pimentel CR, Soares LSH, Macieira RM, Joyeux JC (2018) Trophic relationships in tidepool fish assemblages of the tropical Southwestern Atlantic. Marine Ecology 39:1-11

Rasband WS, (1997) ImageJ, U.S. National Institutes of Health, Bethesda, Maryland, USA

Reeves SE, Kriegisch N, Johnson CR, Ling SD (2018) Reduced resistance to sediment-trapping turfs with decline of native kelp and establishment of an exotic kelp. Oecologia 188:1239-1251

Reynolds LK, Marino R, Muth MF, McLenaghan N, Hayn M, Tyler AC, McGlathery, Howarth RW (2015) Evidence of grazer control on nitrogen fixation by eelgrass epiphytes in a temperate coastal bay. Marine Ecology Progress Series 526:11-19

Ross ST (1986) Resource partitioning in fish assemblages: a review of field studies. Copeia 352-388

Sale PF (1978) Coexistence of coral reef fishes - a lottery for living space. Environmental Biology of Fishes 3:85-102

Schmidt AL, Scheibling RE (2007) Effects of native and invasive macroalgal canopies on composition and abundance of mobile benthic macrofauna and turf-forming algae. Journal of Experimental Marine Biology and Ecology 341:110-130

Strain EM, Thomson RJ, Micheli F, Mancuso FP, Airoldi L (2014) Identifying the interacting roles of stressors in driving the global loss of canopy-forming to mat-forming algae in marine ecosystems. Global Change Biology 20(11): 3300-3312

Széchy MD, Paula ED (2000) Padrões estruturais quantitativos de bancos de Sargassum (Phaeophyta, Fucales) do litoral dos estados do Rio de Janeiro e São Paulo, Brasil. Revista Brasileira de Botânica 23(2): 121132

Széchy MD, Galliez M, Marconi MI (2006) Quantitative variables applied to phenological studies of Sargassum vulgare c. Agardh (phaeophyceae-Fucales) from Ilha Grande Bay, State of Rio de Janeiro. Brazilian Journal of Botany 29(1):27-37

Tait LW, Schiel DR (2011) Legacy effects of canopy disturbance on ecosystem functioning in macroalgal assemblages. PLOS one 6(10) e26986

Tano S, Eggertsen M, Wikström SA, Berkström C, Buriyo AS, Halling C (2016) Tropical seaweed beds are important habitats for mobile invertebrate epifauna. Estuarine, Coastal and Shelf Science 183: 1-12

Tavares MR, Costa PAS, Ventura CRR (2019) Population size structure, asexual reproduction, and somatic growth estimates of the non-indigenous brittle star Ophiothela mirabilis (Echinodermata: Ophiuroidea) on the southeastern coast of Brazil. Marine Biodiversity 49:1713-1725

Underwood AJ (1997) Experiments in ecology: their logical design and interpretation using analysis of variance Cambridge University Press, Cambridge

van Oevelen D, Soetaert K, Middelburg JJ, Herman PMJ, Moodley L, Hamels I, Moens T, Heip CHR (2006) Carbon flows through a benthic food web: Integrating biomass, isotope and tracer data. Journal of Marine Research 64:453-482 
Veloso APA, de Szcéchy MTM (2008) Variações temporais no desenvolvimento vegetativo reprodutivo macroalga Sargassum c. Agardh (fucales, phaeophyceae) - síntese do conhecimento. Oecologia Brasiliensis 12(2):275-290

Vizzini S, Mazzola A (2003) Seasonal variations in the stable carbon and nitrogen isotope ratios (C-13/C-12 and $\mathrm{N}-15 / \mathrm{N}-14$ ) of primary producers and consumers in a western Mediterranean coastal lagoon. Marine Biology 142:1009-1018

Wikström SA, Kautsky L (2007) Structure and diversity of invertebrate communities in the presence and absence of canopy-forming Fucus vesiculosus in the Baltic Sea. Estuarine, Coastal and Shelf Science 72(1): $168-176$

Yodzis P (1986) Competition, mortality and community structure. In: Community Ecology (Diamond J, Case TJ eds), pp. 480-491. Harper \& Row, New York 


\section{Supplementary material}

Table S1. Overall abundance of major invertebrate taxonomic groups, as individuals per plot, associated to algal canopies (Sargassum spp., Galaxaura marginata) and turfs (filamentous and coralline) from December 2017 to March 2018. NI: non-identifiable individuals.

\begin{tabular}{|c|c|c|c|c|c|c|c|c|c|c|c|c|}
\hline \multirow[b]{3}{*}{ Groups } & \multicolumn{6}{|c|}{ Sargassum sp } & \multicolumn{6}{|c|}{ Galaxaura marginata } \\
\hline & \multicolumn{2}{|c|}{ Guaecá } & \multicolumn{2}{|c|}{ P. Montada } & \multicolumn{2}{|c|}{ Zimbro } & \multicolumn{2}{|c|}{ Guaecá } & \multicolumn{2}{|c|}{ P. Montada } & \multicolumn{2}{|c|}{ Zimbro } \\
\hline & mean & SE & mean & SE & mean & SE & mean & SE & mean & SE & mean & SE \\
\hline Gastropods & 240,0 & 24,7 & 463,5 & 58,9 & 380,0 & 41,4 & 261,0 & 24,1 & 363,3 & 69,4 & 650,5 & 81,5 \\
\hline Bivalves & 93,8 & 20,9 & 67,5 & 12,6 & 102,3 & 21,0 & 137,8 & 12,7 & 50,8 & 11,1 & 247,5 & 95,6 \\
\hline Polichaetes & 45,5 & 11,3 & 110,5 & 29,3 & 104,3 & 18,6 & 62,3 & 28,9 & 58,0 & 21,7 & 326,8 & 84,6 \\
\hline Brachyuran crabs & 47,3 & 5,1 & 29,0 & 6,5 & 105,8 & 14,4 & 49,3 & 8,7 & 31,3 & 7,5 & 94,5 & 8,8 \\
\hline Amphipods & 24,0 & 4,1 & 39,5 & 4,4 & 58,0 & 17,1 & 13,8 & 2,1 & 36,3 & 2,8 & 127,5 & 27,8 \\
\hline Tanaids & 24,8 & 9,7 & 70,8 & 28,9 & 41,3 & 10,9 & 23,8 & 12,7 & 28,0 & 3,0 & 177,8 & 62,4 \\
\hline Hermit crabs & 22,8 & 2,3 & 21,0 & 4,9 & 15,0 & 5,7 & 17,3 & 5,0 & 28,3 & 7,1 & 18,0 & 2,3 \\
\hline Caridean shrimps & 3,3 & 1,8 & 0,3 & 0,2 & 1,5 & 0,3 & 2,3 & 0,5 & 4,5 & 1,7 & 1,8 & 0,5 \\
\hline Chitons & 0,8 & 0,2 & 0,0 & 0,0 & 0,3 & 0,2 & 0,8 & 0,4 & 1,3 & 0,2 & 0,5 & 0,3 \\
\hline Brittle stars & 121,5 & 35,4 & 71,0 & 11,6 & 84,5 & 17,6 & 98,3 & 33,7 & 96,5 & 12,9 & 141,0 & 37,6 \\
\hline Isopods & 6,3 & 4,6 & 1,8 & 0,6 & 6,0 & 2,3 & 0,8 & 0,2 & 0,5 & 0,4 & 7,8 & 2,2 \\
\hline Sea spiders & 10,3 & 1,8 & 9,8 & 4,6 & 37,3 & 11,0 & 9,5 & 1,6 & 3,3 & 0,7 & 12,3 & 2,1 \\
\hline Sipunculids & 1,5 & 0,6 & 3,8 & 1,3 & 0,8 & 0,4 & 1,5 & 1,0 & 0,3 & 0,2 & 1,5 & 1,0 \\
\hline Limpets & 7,5 & 3,2 & 11,3 & 2,0 & 6,3 & 1,4 & 5,8 & 1,6 & 14,0 & 6,6 & 14,0 & 2,2 \\
\hline Flat worms & 0,3 & 0,2 & 0,3 & 0,2 & 0,5 & 0,3 & 0,8 & 0,4 & 0,5 & 0,4 & 0,8 & 0,4 \\
\hline Nemertines & 0,3 & 0,2 & 0,5 & 0,4 & 0,3 & 0,2 & 0,0 & 0,0 & 0,0 & 0,0 & 0,5 & 0,4 \\
\hline Copepods & 0,0 & 0,0 & 5,8 & 4,7 & 0,8 & 0,6 & 11,5 & 10,0 & 0,0 & 0,0 & 13,3 & 7,2 \\
\hline Ostracods & 0,5 & 0,3 & 1,0 & 0,4 & 9,3 & 7,4 & 0,3 & 0,2 & 0,0 & 0,0 & 26,3 & 10,6 \\
\hline Foraminiferans & 1,0 & 0,6 & 2,5 & 1,1 & 4,3 & 2,3 & 0,8 & 0,4 & 0,0 & 0,0 & 12,0 & 5,8 \\
\hline Oligochaetes & 0,3 & 0,2 & 0,3 & 0,2 & 0,5 & 0,4 & 0,0 & 0,0 & 0,3 & 0,2 & 0,3 & 0,2 \\
\hline Cumaceans & 0,0 & 0,0 & 0,0 & 0,0 & 0,3 & 0,2 & 1,0 & 0,9 & 0,0 & 0,0 & 0,8 & 0,6 \\
\hline Echiurans & 0,0 & 0,0 & 0,0 & 0,0 & 0,8 & 0,4 & 0,8 & 0,4 & 0,3 & 0,2 & 1,0 & 0,4 \\
\hline Sea urchins & 0,0 & 0,0 & 0,0 & 0,0 & 1,3 & 0,5 & 0,3 & 0,2 & 1,0 & 0,6 & 0,3 & 0,2 \\
\hline Sea stars & 1,0 & 0,4 & 0,3 & 0,2 & 0,0 & 0,0 & 1,3 & 0,4 & 1,0 & 0,6 & 0,0 & 0,0 \\
\hline Sea hares & 0,3 & 0,2 & 0,0 & 0,0 & 0,0 & 0,0 & 0,0 & 0,0 & 0,0 & 0,0 & 0,0 & 0,0 \\
\hline Nudibranchs & 0,0 & 0,0 & 1,0 & 0,4 & 0,0 & 0,0 & 0,0 & 0,0 & 0,0 & 0,0 & 1,3 & 0,6 \\
\hline Onchidella sp & 1,0 & 0,4 & 1,0 & 0,5 & 0,3 & 0,2 & 0,5 & 0,4 & 0,0 & 0,0 & 0,3 & 0,2 \\
\hline megalopae & 0,0 & 0,0 & 0,0 & 0,0 & 0,0 & 0,0 & 0,0 & 0,0 & 0,0 & 0,0 & 0,0 & 0,0 \\
\hline Fish & 0,3 & 0,2 & 0,0 & 0,0 & 0,0 & 0,0 & 0,0 & 0,0 & 0,0 & 0,0 & 0,0 & 0,0 \\
\hline NI & 0,0 & 0,0 & 0,8 & 0,6 & 1,3 & 0,8 & 0,8 & 0,2 & 2,0 & 1,5 & 1,3 & 1,1 \\
\hline
\end{tabular}


Table S1 - Continued

\begin{tabular}{|c|c|c|c|c|c|c|c|c|c|c|c|c|}
\hline \multirow[b]{3}{*}{ Groups } & \multicolumn{6}{|c|}{ Filamentous turf } & \multicolumn{6}{|c|}{ Coralline turf } \\
\hline & \multicolumn{2}{|c|}{ Guaecá } & \multicolumn{2}{|c|}{ P. Montada } & \multicolumn{2}{|c|}{ Zimbro } & \multicolumn{2}{|c|}{ Guaecá } & \multicolumn{2}{|c|}{ P. Montada } & \multicolumn{2}{|c|}{ Zimbro } \\
\hline & mean & SE & mean & SE & mean & SE & mean & SE & mean & $\mathrm{SE}$ & mean & $\mathrm{SE}$ \\
\hline Gastropods & 114,5 & 24,5 & 87,8 & 19,7 & 15,3 & 3,9 & 67,3 & 13,8 & 132,0 & 21,9 & 43,5 & 14,8 \\
\hline Bivalves & 72,8 & 8,7 & 63,3 & 26,9 & 57,8 & 9,1 & 79,0 & 20,3 & 49,8 & 11,6 & 92,3 & 32,9 \\
\hline Polychaetes & 241,5 & 41,1 & 79,5 & 20,7 & 126,3 & 27,2 & 286,5 & 47,8 & 134,0 & 28,1 & 360,8 & 79,4 \\
\hline Brachyuran crabs & 60,5 & 20,0 & 13,8 & 6,7 & 3,8 & 1,1 & 29,3 & 4,6 & 17,3 & 4,5 & 67,8 & 14,0 \\
\hline Amphipods & 63,8 & 21,6 & 16,3 & 7,8 & 63,0 & 10,0 & 64,3 & 18,5 & 21,5 & 5,3 & 78,0 & 10,9 \\
\hline Tanaids & 134,0 & 40,1 & 28,5 & 11,0 & 148,0 & 11,1 & 240,8 & 132,8 & 35,5 & 5,9 & 59,0 & 12,3 \\
\hline Hermit crabs & 18,0 & 5,4 & 10,3 & 3,6 & 1,5 & 1,0 & 17,0 & 4,9 & 18,5 & 5,5 & 5,0 & 1,7 \\
\hline Caridean shrimps & 3,5 & 1,3 & 1,3 & 1,1 & 0,3 & 0,2 & 2,8 & 1,1 & 0,5 & 0,4 & 1,5 & 0,6 \\
\hline Chitons & 15,0 & 3,5 & 5,8 & 3,8 & 0,0 & 0,0 & 13,8 & 3,6 & 2,8 & 0,4 & 4,3 & 3,1 \\
\hline Brittle stars & 97,0 & 38,5 & 79,3 & 20,4 & 6,3 & 3,7 & 133,8 & 35,3 & 138,0 & 35,3 & 71,0 & 20,3 \\
\hline Isopods & 0,8 & 0,6 & 0,0 & 0,0 & 0,0 & 0,0 & 0,5 & 0,3 & 0,3 & 0,2 & 1,3 & 0,6 \\
\hline Sea spiders & 7,5 & 1,3 & 7,0 & 1,6 & 1,0 & 0,4 & 12,0 & 2,2 & 9,5 & 1,1 & 4,0 & 0,6 \\
\hline Sipunculids & 2,8 & 0,6 & 2,3 & 1,2 & 0,3 & 0,2 & 5,0 & 0,9 & 4,8 & 2,7 & 0,5 & 0,4 \\
\hline Limpets & 17,0 & 5,0 & 4,3 & 0,5 & 9,3 & 1,1 & 12,5 & 3,4 & 8,5 & 1,1 & 6,8 & 1,8 \\
\hline Flat worms & 5,5 & 3,2 & 1,3 & 0,8 & 40,5 & 8,3 & 15,3 & 5,6 & 1,0 & 0,4 & 36,5 & 4,1 \\
\hline Nemertines & 0,3 & 0,2 & 0,3 & 0,2 & 0,3 & 0,2 & 0,3 & 0,2 & 0,0 & 0,0 & 0,3 & 0,2 \\
\hline Copepods & 0,0 & 0,0 & 0,0 & 0,0 & 0,8 & 0,4 & 0,3 & 0,2 & 0,0 & 0,0 & 0,5 & 0,4 \\
\hline Ostracods & 2,0 & 0,4 & 1,3 & 1,1 & 0,3 & 0,2 & 1,3 & 0,5 & 1,3 & 0,4 & 0,0 & 0,0 \\
\hline Foraminiferans & 1,3 & 0,8 & 0,3 & 0,2 & 0,0 & 0,0 & 0,0 & 0,0 & 0,8 & 0,4 & 0,0 & 0,0 \\
\hline Oligochaetes & 2,5 & 1,6 & 0,0 & 0,0 & 1,5 & 0,6 & 2,0 & 0,9 & 1,0 & 0,5 & 1,3 & 0,5 \\
\hline Cumaceans & 0,3 & 0,2 & 0,0 & 0,0 & 0,0 & 0,0 & 0,0 & 0,0 & 0,0 & 0,0 & 0,0 & 0,0 \\
\hline Echiurans & 0,0 & 0,0 & 0,0 & 0,0 & 0,0 & 0,0 & 0,0 & 0,0 & 0,0 & 0,0 & 0,3 & 0,2 \\
\hline Sea urchins & 3,8 & 1,5 & 1,3 & 0,8 & 0,3 & 0,2 & 4,8 & 1,5 & 2,5 & 0,8 & 0,3 & 0,2 \\
\hline Sea stars & 0,5 & 0,3 & 0,0 & 0,0 & 0,0 & 0,0 & 0,0 & 0,0 & 0,3 & 0,2 & 0,0 & 0,0 \\
\hline Sea hares & 0,3 & 0,2 & 0,0 & 0,0 & 0,3 & 0,2 & 0,0 & 0,0 & 0,0 & 0,0 & 0,0 & 0,0 \\
\hline Nudibranchs & 0,3 & 0,2 & 0,0 & 0,0 & 0,0 & 0,0 & 0,3 & 0,2 & 0,5 & 0,3 & 0,3 & 0,2 \\
\hline Onchidella sp & 1,0 & 0,6 & 0,3 & 0,2 & 0,3 & 0,2 & 0,0 & 0,0 & 0,0 & 0,0 & 1,3 & 0,8 \\
\hline Megalopae & 0,3 & 0,2 & 0,0 & 0,0 & 0,3 & 0,2 & 0,0 & 0,0 & 0,0 & 0,0 & 0,0 & 0,0 \\
\hline Fish & 0,0 & 0,0 & 0,0 & 0,0 & 0,0 & 0,0 & 0,3 & 0,2 & 0,0 & 0,0 & 0,0 & 0,0 \\
\hline NI & 0,8 & 0,4 & 2,0 & 1,0 & 1,8 & 1,0 & 5,0 & 2,4 & 1,8 & 0,5 & 4,3 & 1,2 \\
\hline
\end{tabular}


Table S2. Canopy vs turf - Similarity percentage (SIMPER) analyses identifying the invertebrate groups that contributed the most (> 7\% dissimilarity, in grey shade) to statistically significant planned contrasts following the omnibus permutational analysis of variance (see 'material \& methods' and figure 2). NI: non-identifiable individuals.

\begin{tabular}{|c|c|c|c|c|c|c|c|c|c|c|c|}
\hline \multicolumn{3}{|c|}{ Guaecá } & \multicolumn{6}{|c|}{ Pedra Montada } & \multicolumn{3}{|c|}{ Zimbro } \\
\hline \multicolumn{3}{|c|}{ Canopy vs Turf } & \multicolumn{3}{|c|}{ Canopy vs Turf } & \multicolumn{3}{|c|}{$\begin{array}{c}\text { Between canopies: } \\
\text { Sargassum vs Galaxaura }\end{array}$} & \multicolumn{3}{|c|}{ Canopy vs Turf } \\
\hline Taxon & $\%$ & Cum \% & Taxon & $\%$ & Cum \% & Taxon & $\%$ & Cum \% & Taxon & $\%$ & Cum $\%$ \\
\hline Polychaetes & 15.51 & 15.51 & Gastropods & 23.45 & 23.45 & Gastropods & 11.66 & 11.66 & Gastropods & 23.28 & 23.28 \\
\hline Tanaids & 13.32 & 28.84 & Polychaetes & 8.65 & 32.09 & Polychaetes & 11.04 & 22.70 & Brittle stars & 8.08 & 31.36 \\
\hline Gastropods & 11.68 & 40.52 & Brittle stars & 7.21 & 39.30 & Tanaids & 8.82 & 31.52 & Flat worms & 7.63 & 38.99 \\
\hline Brittle stars & 7.71 & 48.23 & Bivalves & 6.28 & 45.58 & Bivalves & 5.95 & 37.46 & Brachyuran crabs & 7.50 & 46.50 \\
\hline Amphipods & 5.69 & 53.92 & Tanaids & 5.67 & 51.24 & Brittle stars & 5.27 & 42.73 & Polychaetes & 7.37 & 53.86 \\
\hline Chitons & 5.07 & 58.99 & Amphipods & 5.41 & 56.66 & Caridean shrimps & 4.79 & 47.52 & Bivalves & 5.91 & 59.77 \\
\hline Bivalves & 4.95 & 63.94 & Brachyuran crabs & 5.31 & 61.97 & Brachyuran crabs & 4.56 & 52.09 & Tanaids & 5.77 & 65.53 \\
\hline Flat worms & 3.86 & 67.80 & Hermit crabs & 4.96 & 66.93 & Hermit crabs & 4.34 & 56.42 & Sea spiders & 4.58 & 70.12 \\
\hline Brachyuran crabs & 3.33 & 71.13 & Sea spiders & 3.08 & 70.01 & Limpets & 4.28 & 60.70 & Ostracods & 3.91 & 74.02 \\
\hline Sea urchins & 3.03 & 74.16 & Sipunculids & 3.06 & 73.07 & Sea spiders & 4.22 & 64.92 & Amphipods & 3.83 & 77.85 \\
\hline Limpets & 2.79 & 76.95 & Limpets & 3.05 & 76.12 & Sipunculids & 4.16 & 69.08 & Hermit crabs & 3.52 & 81.37 \\
\hline Hermit crabs & 2.65 & 79.60 & Chitons & 2.85 & 78.97 & Copepods & 3.58 & 72.65 & Isopods & 2.82 & 84.19 \\
\hline Sipunculids & 1.97 & 81.57 & Caridean shrimps & 2.79 & 81.76 & Foraminiferans & 3.40 & 76.06 & Foraminiferans & 2.77 & 86.96 \\
\hline Isopods & 1.95 & 83.52 & Unidentified & 2.51 & 84.27 & Chitons & 3.02 & 79.07 & Copepods & 2.07 & 89.02 \\
\hline Unidentified & 1.84 & 85.35 & Sea urchins & 2.25 & 86.52 & Isopods & 2.83 & 81.90 & Unidentified & 1.64 & 90.67 \\
\hline Caridean shrimps & 1.82 & 87.17 & Ostracods & 1.82 & 88.34 & Unidentified & 2.68 & 84.58 & Oligochaetes & 1.19 & 91.85 \\
\hline Oligochaetes & 1.78 & 88.95 & Isopods & 1.77 & 90.11 & Nudibranchs & 2.42 & 87.00 & Limpets & 1.17 & 93.02 \\
\hline Ostracods & 1.59 & 90.54 & Flat worms & 1.76 & 91.87 & Ostracods & 2.31 & 89.30 & Caridean shrimps & 1.09 & 94.11 \\
\hline Copepods & 1.48 & 92.02 & Foraminiferans & 1.71 & 93.58 & Amphipods & 2.09 & 91.39 & Chitons & 1.05 & 95.16 \\
\hline Sea stars & 1.32 & 93.34 & Copepods & 1.48 & 95.06 & Onchidella sp & 1.89 & 93.28 & Sipunculids & 0.91 & 96.07 \\
\hline Sea spiders & 1.29 & 94.63 & Sea stars & 1.16 & 96.22 & Sea stars & 1.81 & 95.09 & Echiurans & 0.90 & 96.97 \\
\hline Foraminiferans & 1.24 & 95.87 & Nudibranchs & 1.14 & 97.36 & Sea urchins & 1.79 & 96.88 & Sea urchins & 0.80 & 97.77 \\
\hline Onchidella sp & 1.17 & 97.04 & Oligochaetes & 1.07 & 98.43 & Flat worms & 1.25 & 98.13 & Onchidella sp & 0.73 & 98.50 \\
\hline Cumaceans & 0.59 & 97.63 & Onchidella sp & 0.96 & 99.39 & Oligochaetes & 0.99 & 99.13 & Nemertines & 0.57 & 99.07 \\
\hline Echiurans & 0.55 & 98.18 & Nemertines & 0.61 & 100.00 & Nemertines & 0.87 & 100.00 & Nudibranchs & 0.53 & 99.61 \\
\hline Nemertines & 0.53 & 98.71 & & & & & & & Cumaceans & 0.39 & 100.00 \\
\hline Nudibranchs & 0.51 & 99.22 & & & & & & & & & \\
\hline Sea hares & 0.40 & 99.62 & & & & & & & & & \\
\hline Fish & 0.38 & 100.00 & & & & & & & & & \\
\hline Overall average di & arity & 33.24 & & & 28.64 & & & 22.55 & & & 39.96 \\
\hline
\end{tabular}


Table S3. Overall abundance of major invertebrate taxonomic groups, as individuals per plot, associated to the algal-forming canopy Sargassum spp. and filamentous turfs over time (December 2018 to February 2019), from December 2018 to February 2019. NI: non-identifiable individuals.

\begin{tabular}{|c|c|c|c|c|c|c|c|c|c|c|c|c|}
\hline \multirow[b]{4}{*}{ Groups } & \multicolumn{12}{|c|}{ Sargassum $s p$} \\
\hline & \multicolumn{6}{|c|}{ P. Montada } & \multicolumn{6}{|c|}{ Zimbro } \\
\hline & \multicolumn{2}{|c|}{ Dezembro } & \multicolumn{2}{|c|}{ Janeiro } & \multicolumn{2}{|c|}{ Fevereiro } & \multicolumn{2}{|c|}{ Dezembro } & \multicolumn{2}{|c|}{ Janeiro } & \multicolumn{2}{|c|}{ Fevereiro } \\
\hline & mean & SE & mean & SE & mean & SE & mean & SE & mean & $\mathrm{SE}$ & mean & SE \\
\hline Gastropods & 305,3 & 152,7 & 494,0 & 123,2 & 461,0 & 9,5 & 67,8 & 15,0 & 268,3 & 61,8 & 548,3 & 39,3 \\
\hline Bivalves & 29,3 & 11,9 & 147,3 & 37,0 & 297,0 & 26,4 & 29,0 & 8,9 & 92,8 & 20,7 & 149 & 22,8 \\
\hline Polychaetes & 103,3 & 21,5 & 82,3 & 63,9 & 68,8 & 13,3 & 196,3 & 127,5 & 40,5 & 12,6 & 9,5 & 5,1 \\
\hline Brachyuran crabs & 20,8 & 3,9 & 13,5 & 3,1 & 9,3 & 1,7 & 28,5 & 9,2 & 11,5 & 2,5 & 27,5 & 4,5 \\
\hline Amphipods & 67,3 & 15,1 & 26,8 & 6,9 & 49,3 & 14,4 & 122,8 & 16,2 & 15,3 & 6,7 & 3 & 0,7 \\
\hline Tanaids & 22,0 & 8,0 & 51,8 & 18,9 & 30,0 & 8,7 & 25,5 & 10,1 & 24,8 & 3,1 & 6,75 & 2,4 \\
\hline Hermit crabs & 93,8 & 35,5 & 34,8 & 21,1 & 22,5 & 3,1 & 9,8 & 2,4 & 0,8 & 0,5 & 10,5 & 4,6 \\
\hline Caridean shrimps & 1,5 & 0,6 & 0,0 & 0,0 & 0,5 & 0,5 & 0,3 & 0,3 & 0,3 & 0,3 & 0 & 0,0 \\
\hline Chitons & 0,5 & 0,3 & 0,8 & 0,5 & 14,3 & 14,3 & 10,3 & 5,6 & 0,0 & 0,0 & 0 & 0,0 \\
\hline Brittle stars & 95,5 & 15,6 & 48,3 & 13,4 & 58,5 & 12,4 & 181,8 & 45,4 & 23,5 & 20,2 & 6,5 & 2,6 \\
\hline Isopods & 0,0 & 0,0 & 0,0 & 0,0 & 1,5 & 0,9 & 2,5 & 0,5 & 0,8 & 0,5 & 0 & 0,0 \\
\hline Sea spiders & 5,0 & 2,4 & 8,0 & 2,9 & 14,0 & 3,4 & 13,5 & 4,1 & 14,0 & 6,8 & 6,75 & 3,1 \\
\hline Sipunculids & 2,0 & 0,7 & 0,0 & 0,0 & 1,8 & 0,9 & 0,3 & 0,3 & 0,0 & 0,0 & 0,25 & 0,3 \\
\hline Limpets & 16,0 & 5,2 & 8,3 & 2,6 & 1,0 & 0,4 & 5,3 & 2,2 & 9,0 & 3,2 & 18,5 & 2,4 \\
\hline Flat worms & 0,5 & 0,5 & 0,0 & 0,0 & 0,3 & 0,3 & 1,8 & 1,4 & 0,0 & 0,0 & 0 & 0,0 \\
\hline Nemertines & 0,3 & 0,3 & 0,0 & 0,0 & 0,0 & 0,0 & 0,8 & 0,5 & 0,0 & 0,0 & 0 & 0,0 \\
\hline Copepods & 0,0 & 0,0 & 18,0 & 8,3 & 11,0 & 10,0 & 0,0 & 0,0 & 13,0 & 11,1 & 1 & 0,4 \\
\hline Ostracods & 1,3 & 0,6 & 1,5 & 0,6 & 8,3 & 4,6 & 0,8 & 0,3 & 2,8 & 1,4 & 37 & 5,6 \\
\hline Foraminiferans & 2,5 & 1,0 & 0,0 & 0,0 & 0,0 & 0,0 & 0,0 & 0,0 & 0,0 & 0,0 & 0 & 0,0 \\
\hline Oligochaetes & 0,0 & 0,0 & 0,0 & 0,0 & 0,0 & 0,0 & 0,3 & 0,3 & 0,0 & 0,0 & 0 & 0,0 \\
\hline Cumaceans & 0,0 & 0,0 & 0,0 & 0,0 & 0,0 & 0,0 & 0,0 & 0,0 & 0,0 & 0,0 & 0 & 0,0 \\
\hline Echiurans & 0,0 & 0,0 & 0,0 & 0,0 & 0,0 & 0,0 & 1,8 & 1,4 & 0,0 & 0,0 & 0 & 0,0 \\
\hline Sea urchins & 6,0 & 1,8 & 6,3 & 1,3 & 1,0 & 0,4 & 1,5 & 0,6 & 2,5 & 1,8 & 2,75 & 1,1 \\
\hline Sea stars & 0,0 & 0,0 & 0,0 & 0,0 & 0,0 & 0,0 & 0,0 & 0,0 & 0,0 & 0,0 & 0 & 0,0 \\
\hline Sea hares & 0,0 & 0,0 & 0,0 & 0,0 & 0,0 & 0,0 & 0,3 & 0,3 & 0,0 & 0,0 & 0 & 0,0 \\
\hline Nudibranchs & 0,5 & 0,3 & 0,0 & 0,0 & 0,0 & 0,0 & 0,0 & 0,0 & 0,0 & 0,0 & 0 & 0,0 \\
\hline Onchidella sp & 0,3 & 0,3 & 0,0 & 0,0 & 0,0 & 0,0 & 0,3 & 0,3 & 0,0 & 0,0 & 0,25 & 0,3 \\
\hline Megalopae & 0,0 & 0,0 & 0,0 & 0,0 & 0,0 & 0,0 & 0,0 & 0,0 & 0,0 & 0,0 & 0 & 0,0 \\
\hline Fish & 0,0 & 0,0 & 0,0 & 0,0 & 0,0 & 0,0 & 0,0 & 0,0 & 0,0 & 0,0 & 0 & 0,0 \\
\hline NI & 0,0 & 0,0 & 0,0 & 0,0 & 0,3 & 0,3 & 0,5 & 0,5 & 0,0 & 0,0 & 3,75 & 1,9 \\
\hline
\end{tabular}


Table S3. Continued.

\begin{tabular}{|c|c|c|c|c|c|c|c|c|c|c|c|c|}
\hline \multirow[b]{4}{*}{ Groups } & \multicolumn{12}{|c|}{ Filamentous turf } \\
\hline & \multicolumn{6}{|c|}{ P. Montada } & \multicolumn{6}{|c|}{ Zimbro } \\
\hline & \multicolumn{2}{|c|}{ Dezembro } & \multicolumn{2}{|c|}{ Janeiro } & \multicolumn{2}{|c|}{ Fevereiro } & \multicolumn{2}{|c|}{ Dezembro } & \multicolumn{2}{|c|}{ Janeiro } & \multicolumn{2}{|c|}{ Fevereiro } \\
\hline & mean & $\mathrm{SE}$ & mean & SE & mean & SE & mean & SE & mean & SE & mean & SE \\
\hline Gastropods & 52,25 & 9,1 & 98,3 & 37,1 & 254,3 & 75,0 & 42,3 & 15,3 & 88,8 & 37,2 & 158,8 & 14,5 \\
\hline Bivalves & 34 & 6,9 & 193,3 & 124,6 & 491,5 & 157,3 & 22,0 & 4,6 & 142,0 & 57,2 & 284,0 & 73,5 \\
\hline Polychaetes & 228,3 & 76,3 & 327,8 & 128,0 & 305,0 & 54,3 & 458,5 & 81,0 & 418,8 & 207,0 & 340,5 & 64,9 \\
\hline Brachyuran crabs & 20,5 & 8,5 & 16,5 & 4,6 & 32,5 & 6,0 & 18,5 & 2,8 & 14,0 & 1,9 & 42,0 & 6,7 \\
\hline Amphipods & 168,3 & 17,5 & 150,8 & 64,2 & 46,3 & 14,7 & 445,8 & 66,3 & 115,3 & 39,7 & 115,8 & 17,6 \\
\hline Tanaids & 83,25 & 34,6 & 93,3 & 13,6 & 105,8 & 38,3 & 88,5 & 14,9 & 112,8 & 28,2 & 99,5 & 36,0 \\
\hline Hermit crabs & 21 & 7,9 & 18,0 & 5,8 & 66,3 & 20,6 & 14,3 & 8,2 & 11,3 & 7,7 & 13,3 & 4,1 \\
\hline Caridean shrimps & 2,75 & 1,4 & 1,3 & 0,8 & 5,8 & 1,9 & 2,5 & 1,0 & 0,8 & 0,5 & 4,0 & 2,0 \\
\hline Chitons & 5,5 & 1,3 & 7,0 & 3,8 & 0,5 & 0,3 & 2,8 & 0,8 & 4,0 & 2,1 & 3,0 & 0,6 \\
\hline Brittle stars & 122,5 & 39,8 & 148,5 & 40,8 & 99,8 & 23,7 & 101,5 & 10,0 & 128,5 & 59,2 & 113,3 & 30,8 \\
\hline Isopods & 2,75 & 1,0 & 3,3 & 2,0 & 3,0 & 1,1 & 13,0 & 3,8 & 1,5 & 0,9 & 1,8 & 0,6 \\
\hline Sea spiders & 9,5 & 3,1 & 9,0 & 4,0 & 11,3 & 1,3 & 5,3 & 1,4 & 4,0 & 1,3 & 15,8 & 9,4 \\
\hline Sipunculids & 2,75 & 1,4 & 4,3 & 2,2 & 2,3 & 1,9 & 0,3 & 0,3 & 1,0 & 0,4 & 0,0 & 0,0 \\
\hline Limpets & 1,75 & 0,8 & 15,0 & 5,3 & 9,3 & 2,3 & 8,8 & 1,8 & 12,5 & 8,8 & 11,3 & 3,1 \\
\hline Flat worms & 4,75 & 1,0 & 15,0 & 8,1 & 4,5 & 1,9 & 34,8 & 7,4 & 21,5 & 10,0 & 21,0 & 10,1 \\
\hline Nemertines & 0,75 & 0,5 & 0,0 & 0,0 & 0,0 & 0,0 & 0,0 & 0,0 & 0,8 & 0,8 & 2,0 & 1,7 \\
\hline Copepods & 3,25 & 1,3 & 1,8 & 1,4 & 1,5 & 0,5 & 16,8 & 8,4 & 2,8 & 1,3 & 2,5 & 1,2 \\
\hline Ostracods & 3,25 & 0,8 & 25,8 & 12,5 & 32,0 & 12,7 & 1,3 & 0,5 & 4,5 & 2,0 & 54,5 & 18,7 \\
\hline Foraminiferans & 0,5 & 0,3 & 0,0 & 0,0 & 18,5 & 7,3 & 0,0 & 0,0 & 0,0 & 0,0 & 10,0 & 5,1 \\
\hline Oligochaetes & 0 & 0,0 & 0,3 & 0,3 & 1,8 & 1,0 & 8,0 & 4,8 & 1,3 & 0,8 & 3,5 & 2,5 \\
\hline Cumaceans & 0,25 & 0,3 & 0,0 & 0,0 & 0,0 & 0,0 & 0,0 & 0,0 & 0,0 & 0,0 & 0,0 & 0,0 \\
\hline Echiurans & 0 & 0,0 & 0,0 & 0,0 & 0,0 & 0,0 & 0,0 & 0,0 & 0,0 & 0,0 & 0,0 & 0,0 \\
\hline Sea urchins & 2 & 0,7 & 6,0 & 1,6 & 4,0 & 1,3 & 1,5 & 0,3 & 3,8 & 2,4 & 17,3 & 9,7 \\
\hline Sea stars & 0 & 0,0 & 0,0 & 0,0 & 0,0 & 0,0 & 0,0 & 0,0 & 0,0 & 0,0 & 0,0 & 0,0 \\
\hline Sea hares & 0 & 0,0 & 0,0 & 0,0 & 0,0 & 0,0 & 0,0 & 0,0 & 0,0 & 0,0 & 0,0 & 0,0 \\
\hline Nudibranchs & 0,75 & 0,5 & 0,0 & 0,0 & 0,3 & 0,3 & 1,0 & 1,0 & 0,5 & 0,5 & 1,0 & 0,7 \\
\hline Onchidella sp & 0,25 & 0,3 & 0,0 & 0,0 & 0,0 & 0,0 & 2,0 & 2,0 & 0,3 & 0,3 & 0,3 & 0,3 \\
\hline Megalopae & 0,5 & 0,3 & 0,0 & 0,0 & 0,3 & 0,3 & 0,3 & 0,3 & 0,5 & 0,5 & 0,0 & 0,0 \\
\hline Fish & 0 & 0,0 & 0,0 & 0,0 & 0,0 & 0,0 & 0,0 & 0,0 & 0,0 & 0,0 & 0,0 & 0,0 \\
\hline NI & 0,25 & 0,3 & 2,0 & 1,7 & 2,5 & 1,0 & 1,5 & 1,5 & 0,3 & 0,3 & 4,3 & 3,1 \\
\hline
\end{tabular}


Table S4. Sargassum canopy vs filamentous turf overtime - Similarity percentage (SIMPER) analyses identifying the invertebrate groups that contributed the most (> 7\% dissimilarity, in grey shade) to statistically significant planned contrasts following the omnibus permutational analysis of variance (see 'material \& methods' and figure 2 ). NI: non-identifiable individuals. t1: December, t2: January, t3: February.

\begin{tabular}{|c|c|c|c|c|c|c|c|c|c|c|c|}
\hline \multicolumn{6}{|c|}{ Pedra Montada } & \multicolumn{6}{|c|}{ Zimbro } \\
\hline \multicolumn{3}{|c|}{ Sargassum t1 vs Sargassum t2 } & \multicolumn{3}{|c|}{ Sargassum t 2 vs Sargassum t 3} & \multicolumn{3}{|c|}{ Sargassum t1 vs Sargassum t2 } & \multicolumn{3}{|c|}{ Sargassum t 2 vs Sargassum t 3} \\
\hline Taxon & $\%$ & Cum \% & Taxon & $\%$ & Cum \% & Taxon & $\%$ & Cum \% & Taxon & $\%$ & Cum \% \\
\hline Gastropods & 17.11 & 17.11 & Bivalves & 14.34 & 14.34 & Brittle stars & 16.97 & 16.97 & Gastropods & 18.87 & 18.87 \\
\hline Bivalves & 13.48 & 30.59 & Polychaetes & 12.18 & 26.52 & Gastropods & 14.51 & 31.49 & Ostracods & 11.85 & 30.72 \\
\hline Polychaetes & 11.87 & 42.45 & Gastropods & 11.62 & 38.14 & Amphipods & 13.54 & 45.03 & Polychaetes & 8.82 & 39.54 \\
\hline Hermit crabs & 10.02 & 52.48 & Copepods & 7.18 & 45.32 & Polychaetes & 10.47 & 55.50 & Bivalves & 7.72 & 47.26 \\
\hline Copepods & 7.46 & 59.93 & Tanaids & 6.69 & 52.00 & Bivalves & 8.14 & 63.64 & Brittle stars & 6.76 & 54.02 \\
\hline Brittle stars & 6.46 & 66.39 & Hermit crabs & 6.05 & 58.05 & Copepods & 4.68 & 68.32 & Tanaids & 6.27 & 60.29 \\
\hline Tanaids & 6.03 & 78.47 & Chitons & 5.33 & 69.18 & Hermit crabs & 4.26 & 76.98 & Copepods & 5.59 & 71.95 \\
\hline Limpets & 3.31 & 81.78 & Brittle stars & 5.16 & 74.33 & Brachyuran crabs & 3.87 & 80.85 & Amphipods & 4.88 & 76.83 \\
\hline Foraminiferans & 2.53 & 84.31 & Ostracods & 4.69 & 79.02 & Tanaids & 2.73 & 83.58 & Sea spiders & 4.79 & 81.61 \\
\hline Sea spiders & 2.39 & 86.70 & Limpets & 4.61 & 83.63 & Sea spiders & 2.59 & 86.17 & Brachyuran crabs & 4.79 & 86.40 \\
\hline Brachyuran crabs & 2.36 & 89.06 & Sea urchins & 3.94 & 87.57 & Limpets & 2.34 & 88.51 & $\mathrm{Ni}$ & 3.90 & 90.30 \\
\hline Sipunculids & 2.35 & 91.40 & Sea spiders & 3.21 & 90.78 & Ostracods & 1.82 & 90.33 & Limpets & 3.81 & 94.11 \\
\hline Caridean shrimps & 2.00 & 93.40 & Sipunculids & 2.82 & 93.60 & Isopods & 1.78 & 92.11 & Sea urchins & 2.46 & 96.56 \\
\hline Ostracods & 1.40 & 94.80 & Isopods & 2.23 & 95.83 & Sea urchins & 1.68 & 93.79 & Isopods & 1.52 & 98.08 \\
\hline Nudibranchs & 0.96 & 98.34 & $\mathrm{Ni}$ & 0.65 & 99.39 & Nemertines & 0.95 & 97.61 & Onchidella sp & 0.62 & 100.00 \\
\hline Flat worms & 0.66 & 99.00 & Flat worms & 0.61 & 100.00 & Caridean shrimps & 0.65 & 98.25 & Flat worms & 0.00 & 100.00 \\
\hline Onchidella sp & 0.53 & 99.53 & Megalopae & 0.00 & 100.00 & $\mathrm{Ni}$ & 0.51 & 98.76 & Megalopae & 0.00 & 100.00 \\
\hline Nemertines & 0.47 & 100.00 & Onchidella sp & 0.00 & 100.00 & Sipunculids & 0.44 & 99.20 & Nudibranchs & 0.00 & 100.00 \\
\hline $\mathrm{Ni}$ & 0.00 & 100.00 & Nudibranchs & 0.00 & 100.00 & Oligochaetes & 0.44 & 99.64 & Echiurans & 0.00 & 100.00 \\
\hline Megalopae & 0.00 & 100.00 & Echiurans & 0.00 & 100.00 & Onchidella sp & 0.36 & 100.00 & Oligochaetes & 0.00 & 100.00 \\
\hline Isopods & 0.00 & 100.00 & Oligochaetes & 0.00 & 100.00 & Megalopae & 0.00 & 100.00 & Foraminiferans & 0.00 & 100.00 \\
\hline Echiurans & 0.00 & 100.00 & Foraminiferans & 0.00 & 100.00 & Nudibranchs & 0.00 & 100.00 & Chitons & 0.00 & 100.00 \\
\hline \multirow[t]{2}{*}{ Oligochaetes } & 0.00 & 100.00 & Nemertines & 0.00 & 100.00 & Foraminiferans & 0.00 & 100.00 & Nemertines & 0.00 & 100.00 \\
\hline & & & Oligochaetes & 0.00 & 100.00 & & & & & & \\
\hline $\begin{array}{l}\text { Overall } \\
\text { average dissimlarity }\end{array}$ & & 31.48 & & & 23.76 & & & 41.72 & & & 30.65 \\
\hline
\end{tabular}



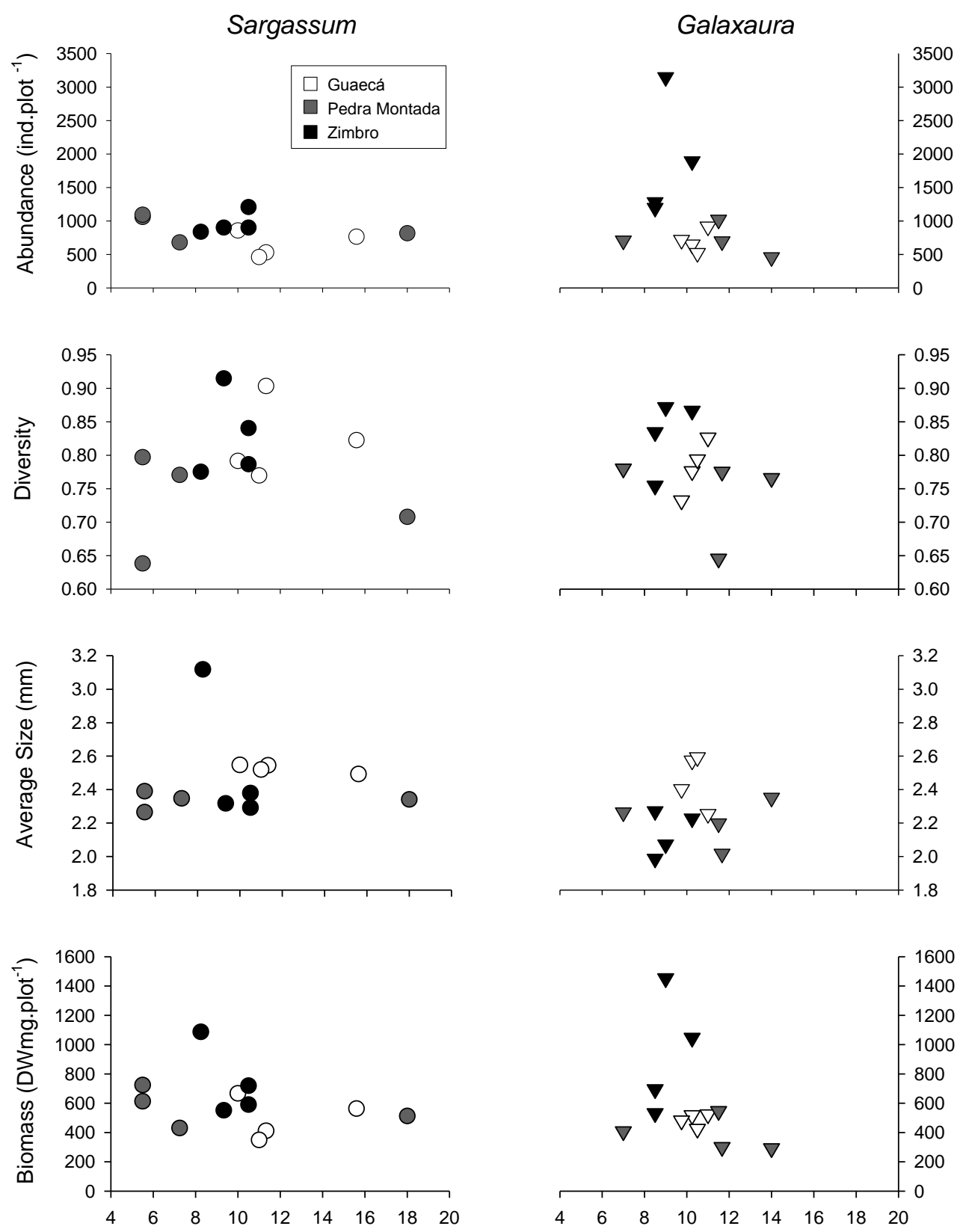

Canopy Height $(\mathrm{cm})$

Fig S1. Relationships between canopy height and univariate metrics of invertebrate assemblages associated to Sargassum spp. and Galaxaura marginata at sampling sites Guaecá, Pedra Montada and Zimbro. Correlation coefficients $(0.03<r<0.34)$ were never significant $(p>0.30$ in all cases). The values of canopy height correspond to averages $(n=5)$ of thallus height within samples. 


\section{Concluding Remarks}

The overall results obtained in this study show that the mobile invertebrate assemblages associated to algal turfs (filamentous and coralline) and algal canopies (Sargassum and Galaxaura) are clearly different, while the assemblages within each of these algal functional types were almost always remarkably similar. Against our expectations, we found a high invertebrate abundance and diversity at turfs, at times higher than at canopies. This finding contrasts to other reports in the literature, which indicate more severe effects of canopy loss. In these latter studies, however, a single canopy species was considered, such as monospecific kelp forests, or the important Mediterranean algal canopy formed by Cystoseira C. Agardh, and many of them were conducted at coastal areas where canopies were already dramatically reduced to very low cover. Despite the overall declining trend of algal canopies in the SW Atlantic, algal canopies are still a major component of the benthic seascape in the São Sebastião Channel (SCC), and therefore the migration of faunal groups from canopies to turfs, as suggested here, may in part explain why our study differs from others.

Maybe more important than concluding on the relative abundance and diversity of mobile invertebrates associated to different vegetated reef habitats, in this case turfs and canopies, would be addressing how heterogeneous reefs harboring a mosaic of complex biogenic substrates compare to more homogeneous seascapes, counting with only a single major ecosystem engineering plant or animal. By providing different subsets of the potential pool of small mobile invertebrates in the area, we conclude that canopies and turfs, together, may sustain a larger diversity (and perhaps abundance) of pelagic consumers that specialize in either type. At present, however, we anticipate a more prominent role of algal canopies as they contribute mostly to sustain large populations of hard-bodied invertebrates, which are preferred prey for 4 out 5 of the most abundant invertivore reef fish in the study area. It is important however that the diet of the reef fished addressed here was mostly based on visual counts of stomach contents, and therefore the consumption of soft-bodied invertebrate groups may be underscored. Visual censuses of fish interactions with the different algal substrates, combined with experimental trials to verify actual feeding preferences would be key to sort out this intriguing and important question.

We also stress that our focus here was on a single ecosystem function of algal habitats - the provision of prey for water-column consumers - and further work on other roles of macroalgal substrates are urgently needed. Closely aligned with this study, further investigations should look at the importance of larger herbivores capable to graze on whole-canopy fronds or scrapping turf areas to barren grounds. Macro-herbivores of this kind include larger browsing fish, such as scarids and kyphosids, or green turtles which are relatively less frequent than most small consumers, but that may play a keystone effect in the area, together with grazing sea-urchin fronts that were observed to leave behind large extensions of bare rock at different places in the SSC and nearby coastal islands. 
Also, the large abundance and diversity observed near complex reef habitats (such as complex vegetated grounds) may not necessarily reflect consumption pressure. Many fish may actually use algal canopies as shelter from their predators. Particularly small fish recruits may find shelter, or concealment, within different algal canopies, and still forage while protected from visual ambush predators. As such, algal canopies may be critical habitats as nursery grounds, a role that has seldom be investigated in structured algal canopies other than kelp forests.

Because of their abundance and structural complexity, the seasonal nature of canopies formed by the brown weed Sargassum spp. deserves further attention. We report an interesting temporal succession of the invertebrate assemblages associated to Sargassum, suggesting that gastropods, bivalves and ostracods outcompete early colonizers as the canopy-blooming season advances. By February, the invertebrate assemblages at Sargassum were already quite distinct from those observed at turfs, now dominated by hard-shelled groups that are apparently preferred by higher-order consumers. This leaves a rather narrow temporal window for this important ecosystem service, as canopy decay would be already in course shortly after during May and April. This opens two important and pending research lines. First, specific experimental research should aim a better understanding the processes underlying the invertebrate assembly during the short Sargassum blooming season. While we had advanced some starting evidence for competition as an overall interaction driving succession, there might be well other sort of biological interactions playing an important role, including within-canopy predation. Second, it is important to understand the mechanisms behind the seasonality of Sargassum in the region, especially the role of small epiphytes growing on the fronds, which accumulate over the season and could reduce photosynthesis to a critical threshold, and any effects of environmental stressors that could modulate such plant-plant interactions. The current decline of canopies in the SW Atlantic is very worrying and any efforts to detect its causes and propose solutions are certainly welcome. There is clearly an undisputable demand for more qualified work on the dynamics of complex vegetated habitats in the region, preferably uniting professional scientists, management planners and decision takers to attempt reverting habitat loss and bring back such important ecosystems to a healthy state. 